\title{
'Waiter! There's a fly in my soup - or is that a cockroach?': The Moral Panic of Dirty Restaurants in the City of Toronto, Canada
}

\author{
by \\ Cherie Leung, B.Sc. (Hons)

\begin{abstract}
A thesis submitted to the Faculty of Graduate Studies and Research

in partial fulfillment of the requirements for the degree of
\end{abstract}

Master of Arts

Department of Law

Carleton University

Ottawa, Ontario

September 1, 2005

(C2005, Cherie Leung 


$\begin{array}{ll}\begin{array}{l}\text { Library and } \\ \text { Archives Canada }\end{array} & \begin{array}{l}\text { Bibliothèque et } \\ \text { Archives Canada }\end{array} \\ \begin{array}{l}\text { Published Heritage } \\ \text { Branch }\end{array} & \begin{array}{l}\text { Direction du } \\ \text { Patrimoine de l'édition }\end{array} \\ \begin{array}{l}\text { 395 Wellington Street } \\ \text { Ottawa ON K1A ON4 }\end{array} & \begin{array}{l}\text { 395, rue Wellington } \\ \text { Ottawa ON K1A ON4 } \\ \text { Canada }\end{array}\end{array}$

Your file Votre référence

ISBN: 0-494-10055-9

Ourfile Notre référence

ISBN: 0-494-10055-9

NOTICE:

The author has granted a nonexclusive license allowing Library and Archives Canada to reproduce, publish, archive, preserve, conserve, communicate to the public by telecommunication or on the Internet, loan, distribute and sell theses worldwide, for commercial or noncommercial purposes, in microform, paper, electronic and/or any other formats.

The author retains copyright ownership and moral rights in this thesis. Neither the thesis nor substantial extracts from it may be printed or otherwise reproduced without the author's permission.
AVIS:

L'auteur a accordé une licence non exclusive permettant à la Bibliothèque et Archives Canada de reproduire, publier, archiver, sauvegarder, conserver, transmettre au public par télécommunication ou par l'Internet, prêter, distribuer et vendre des thèses partout dans le monde, à des fins commerciales ou autres, sur support microforme, papier, électronique et/ou autres formats.

L'auteur conserve la propriété du droit d'auteur et des droits moraux qui protège cette thèse. $\mathrm{Ni}$ la thèse ni des extraits substantiels de celle-ci ne doivent être imprimés ou autrement reproduits sans son autorisation.
In compliance with the Canadian

Privacy Act some supporting forms may have been removed from this thesis.

While these forms may be included in the document page count, their removal does not represent any loss of content from the thesis.
Conformément à la loi canadienne sur la protection de la vie privée, quelques formulaires secondaires ont été enlevés de cette thèse.

Bien que ces formulaires aient inclus dans la pagination, il n'y aura aucun contenu manquant.

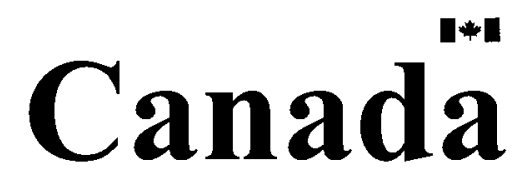




\section{Abstract}

This thesis will study the process of how Toronto's Restaurant Health Inspection and Disclosure System (commonly known as 'DineSafe') emerged as a direct result of one reporter's efforts. The moral panic framework is used to understand how the year long Toronto Star 'Dirty Dining' news serial was effective in affecting change. Elements of moral panic were evident in this series of articles. Namely, public concern was disproportionate to the 'real' risks involved. Restaurant owners were targeted by the media as individuals who knowingly harmed the public by ignoring health codes. The consensus was that this behaviour was 'wrong' and something had to be done. Through his articles, Toronto Star reporter Robert Cribb pushed for increased transparency of health inspection records. By generating a high level of public concern, he was able to put enough pressure on the municipal government to enact immediate change to the existing legislation, resulting in 'DineSafe'. 


\section{Acknowledgments}

This work benefited from the help of individuals who must not go unmentioned. I would like to express my deepest gratitude to Alan Hunt for his contribution and guidance, Dawn Moore and Aaron Doyle for their enthusiasm and valued input, and Andrew Squires (the best Grad Admin ever). Many thanks to Robert Cribb for providing his candid insights during our interview. Finally, thank you to my family and friends who supported me through this whole endeavour. 


\section{Table of Contents}

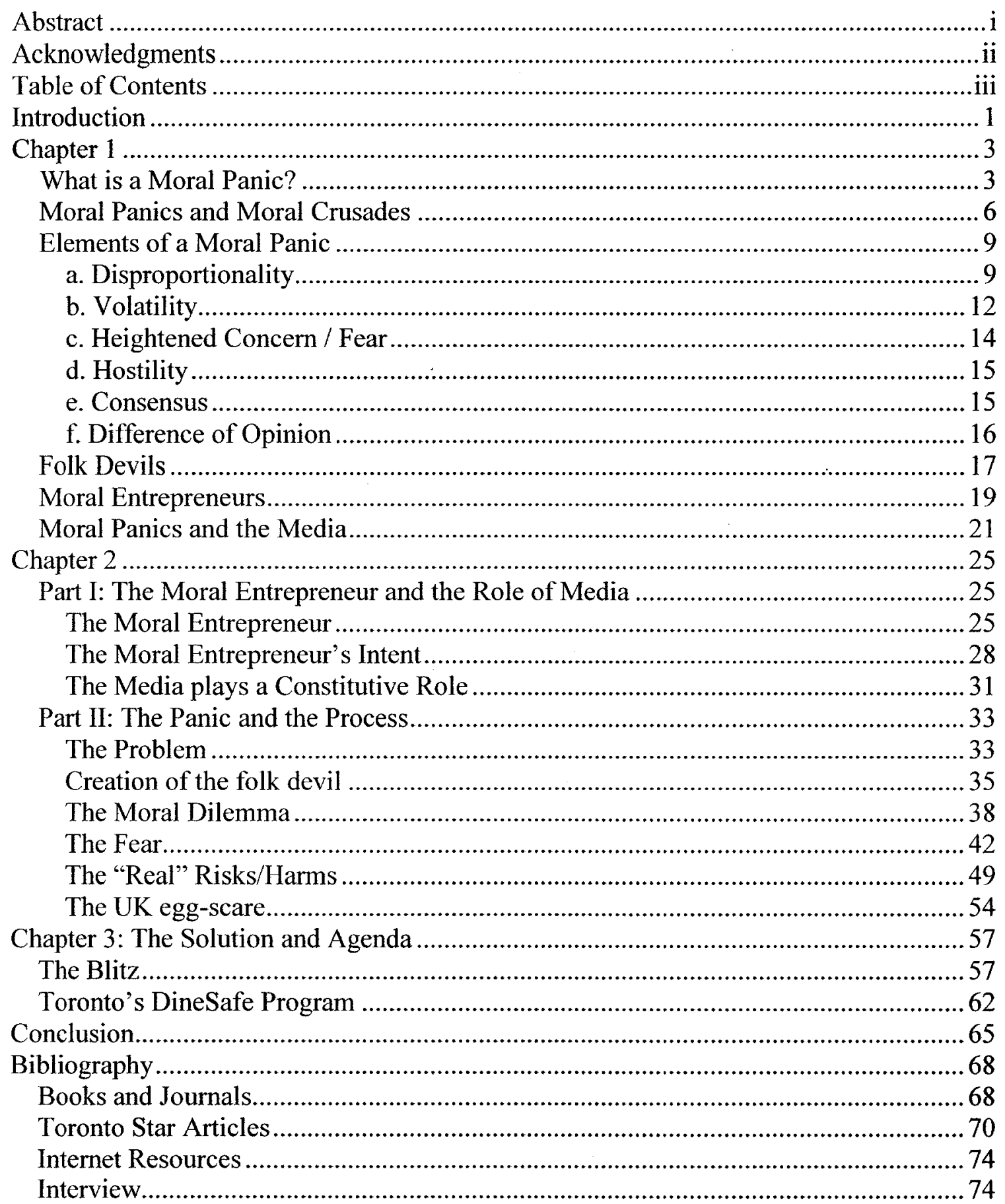




\section{Introduction}

Any citizen or tourist in the City of Toronto, Ontario today will notice colourcoded placards in the windows of its food establishments. These $8 \times 10$ inch cards represent the 'stop and go' reflective of the city's street lights. Green means that the food establishment has passed its recent health inspection. Yellow means consumers should proceed with caution, but can be assured that health inspectors will be back within 48 hours to ensure that minor health infractions have been corrected. Red means the place is a no-go.

These cards, together with the city's website (www.city.toronto.con.ca/fooddisclosure/) and telephone hotline (416-338-FOOD) are part of Toronto's Food Premises Inspection and Disclosure system, commonly known as DineSafe. As of January 2001, this system required all owners and operators in the city to meet standards listed in the Food Premises Regulation (Ontario Regulation 562 amended under the Health Protection and Promotion Act) and comply with amendments to Toronto Licensing By-Law 574-2000. With regards to the latter piece of legislation, consumers can obtain detailed inspection records of the food establishment of their choice in order to make informed decisions about the restaurants they patronize. The coloured restaurant grade cards in every window are an obvious sign telling consumers whether it is 'safe' for them to dine. 
First enacted in January 2001, DineSafe is a relatively new initiative for the City of Toronto, and quite unique with only a handful of cities around the world participating in similar disclosure methods. The success of the system since has made Toronto an example for other cities in Canada as well as abroad. This thesis will show how the current system emerged as a direct result of a long-standing Toronto Star series entitled 'Dirty Dining' by staff news reporter Robert Cribb. In the model of the 'moral panic', pioneered by Stanely Cohen (1972), this thesis analyzes the media and public reaction to show how one individual's concern over lack of government transparency with regards to restaurant health inspection in the city of Toronto led to an eventual change in municipal legislation.

The first chapter will introduce the concept of the moral panic and its necessary components. This will then be applied in the second chapter to the issue of dirty restaurants in Toronto to study the situation using the established framework. Finally, the last chapter examines the resulting changes to Toronto's restaurant inspection policy. 


\section{Chapter 1}

\section{What is a Moral Panic?}

Moral panic as a phenomenon is a relatively new concept, though it has its origins in other like concepts. As far back as the mid-1800s, writers such as Charles Mackay (1841) and Gustave LeBon (1895) wrote on ideas of mass popular delusions and extreme irrational crowd behaviour, respectively, both of which are precursors today's idea of the moral panic.

The term 'moral panic' was first coined in 1971 by the criminologist Jock Young in his work on the sociological construction of drug users, though Stanley Cohen is credited for systematically introducing the concept. Upon studying public reaction towards alarming increases in drug use reported by statistics, Young noted that "the moral panic over drug-taking results in the setting-up of drug squads' by police departments, which produces an increase in drug-related arrests" (Young $1971 \mathrm{cf}$. Thompson 1998: 7). As a topic of sociological inquiry, 'moral panic' was first addressed in detail in the work of British sociologist Stanley Cohen, who used it to describe media and public reactions, as well as the strengthening of social control mechanisms towards youth disturbances resulting from the seaside fights between the Mods ${ }^{1}$ and Rockers in 1960s Britain (Thompson 1998:7, Cohen 1972). In his well-known book (1972), Folk Devils and Moral Panics, he defined a moral panic as:

\footnotetext{
${ }^{\mathrm{I}}$ Short for Moderns
} 
"A condition, episode, person or group of persons [that] emerges to become defined as a threat to societal values and interests; its nature is presented in a stylized and stereotypical fashion by the mass media; the moral barricades are manned by editors, bishops, politicians and other right-thinking people; socially accredited experts pronounce their diagnoses and solutions; ways of coping are evolved or (more often) resorted to; the condition then disappears, submerges or deteriorates and becomes more visible. Sometimes the object of the panic is quite novel and at other times it is something which has been in existence long enough, but suddenly appears in the limelight. Sometimes the panic passes over and is forgotten, except in folklore and collective memory; at other times it has more serious and long-lasting repercussions and might produce such changes as those in legal and social policy or even in the way the society conceives itself." (Cohen $1972,9)$

Both Cohen and Young address the importance of looking at the media, as well as public opinion groups and the actions of law makers and police. Though the 'moral panic' has been used to describe other events such as The Renaissance Witch Craze (BenYehuda 1985; Goode \& Ben-Yehuda 1994: 144-184) and Satanism (Bromley 1991), it must be remembered that the first models used to exemplify the concept were rooted in a criminological perspective, and more broadly in the sociology of deviance. It is in this light that the 'moral' aspect in the discussion of moral panics should be regarded first and 
foremost with reference to the nature of deviance within the topic as opposed to one solely of religious tendencies.

At first glance, one might immediately apply a negative judgment to the term moral panic and dismiss it as something not intrinsically worth worrying about because of the inherent sensationalist quality the concept bears. Some think that "the very term 'moral panics' seems to imply a negative judgment, implying naiveté on the part of some of those involved and the manipulation on the part of others. Even the word 'panic' might well be regarded as an unfortunate choice, dismissed as irrational" (Thompson 1998: viii). However, rather than repudiating this subject of study, it should be realized that there is much deeper meaning that lies beneath all the events in a moral panic. According to Springhall, too much usage of the term consists of those "obsessed by the debunking notion of 'demystification'....It usually comes equipped with research which demonstrates that alcohol consumption was in fact at its peak in the $1870 \mathrm{~s}$, or that football hooliganism actually began in $1898 "$ (1998: 8). Instead of focusing on 'debunking' moral panics as urban myths, a more constructive endeavor would be to look within the concerns of moral panics to further understand what the events, behaviours, and reactions tells us about society. According to Thompson, "(p)rovided care is taken to avoid jumping to conclusions about the motivations (e.g. manipulative) or mental state (e.g. implied 'irrationality') of those involved, the concept of 'moral panic' can be useful in spotlighting a form of behaviour and pattern of events that is increasingly common in our media-saturated (or media-rich) modern society" (1998: viii). 
By analyzing some past examples of moral panics, it is possible to see that there are certain commonalities amongst them. Whether they were witch trials, child abductions, or homosexuality, there seems to be some basic fears to which these point. That is, though it seems obvious that these moral panics of the past are clearly different in terms of the situations and harms they may project, the fears themselves may be the same. For example, a common fear may be the degeneration of society or of a certain segment of society. Whether the moral panic involves widespread satanic rituals performed on children, or restaurant health inspection (something more realistic), "certain assertions about satanic happenings will be relatively unaffected by the lack of evidence" because . "Satanism claims may be metaphorically true even if empirically false" (Bromley 1991: 68). This shows that the fear in moral panics should not be dismissed without evaluating the roots of its fear or anxiety involved. In both cases, closer inspection would be beneficial in identifying the underlying concerns of society and how it acts, rationally or irrationally, to attempt to disperse such fears. As one author rightly notes, "studying moral panics is a powerful sociological tool because it can help us understand a society's fears and folk-devils which helps us to understand the society" (Jenkins 1992: 9).

\section{Moral Panics and Moral Crusades}

The study of moral panics can be located within studies of deviance and studies of collective behaviour (Cohen 1972: 11). Though undoubtedly there are marked differences, moral panic as a social phenomenon bears arms-length similarity to other sociological concepts such as mass hysteria, mass delusion, and reactions to physical 
disasters (Cohen 1972:11). Most notably, the study of moral panic as a concept developed from its predecessor, the moral crusade. In this concept, activists are motivated by moral as opposed to rational and protectionist interests. They believe that certain individuals in society are behaving immorally and take the initiative to rid society of the evil they believe the group is causing (Becker 1963). Though Becker (1963: 148-8) and Gusfield (1955: 223) argue that both moral and rational protectionist measurements can coincide, they are not necessarily true in all cases of moral crusades. This is in contrast to the conception of moral panics because according to Goode and Ben-Yehuda (1994), moral panics "implies a certain disassociation between protectionism and concern that the threat, and therefore that the steps taken to protect the society from that threat may be somewhat misplaced" (20). By this differentiation that the authors provide, it seems that their definition of a moral panic 1) is mutually exclusive to a moral crusade; 2 ) may bear the likeness of a moral crusade but may differ in the intent of action (moral versus rational protectionist); 3) includes motivations that are not focused on changing morals so much as they are focused on ulterior ends.

The authors also assert that a "moral crusade is not necessarily a moral panic", though the two concepts may overlap (Goode and Ben-Yehuda 1994: 19). If intent is the main differentiation between a moral panic and a moral crusade, it is no wonder that these two are often difficult to tease apart as intent itself is difficult to discern. To confound matters further, not only do these two phenomena bear similar qualities, but both terms are often used by scholars to describe similar events (ie. the War on Drugs). A key example is the term, moral entrepreneur. Howard Becker's (1963) term to 
describe those who lead moral crusades as well as panics. Broadly, moral entrepreneurs refer to "organizers, activists, do-gooders, movement advocates who push for a given cause" and while activists are often the ones who start panics, it is not necessarily the case (Goode \& Ben-Yehuda 1994: 20). In short, moral entrepreneurs are crusaders who initiate the moral crusades, and often, but not always, initiate moral panics. The authors clarify further by providing that "To put things another way, the moral entrepreneur creates the crusade: no entrepreneur, no crusade. By definition, the latter is a direct product of the former. In contrast, the engineered, consciously created quality of the moral panic is an empirical, not a definitional, question. It may have been initiated anywhere - by crusaders, by the general public, by political or economic elites, by the media" (Goode \& Ben-Yehuda 1994: 20).

Thompson (1998) argues that contemporary moral panics should not be viewed as a continuation of the past because 1) since moral panics are rapidly emerging everywhere, almost anything can spark a panic; and 2) panics are becoming more and more 'allpervasive'. While earlier panics focused on single groups, such as young adults or drug addicts, "Contemporary panics seem to catch many more people in their net" (Thompson 1998: 2). Though he is right in these claims, it is useful to know the origins of specific moral panics. Similarly, though the moral panic concept diverges from the moral crusade, the latter term bears with it many ideas and examples that as a predecessor, colour the idea of how we view moral panics today with regard to the widespread public alarm and fervour they both cause. It may be the case that, contrary to Springhall (1998), the difference between moral panics and moral crusades can be mainly attributed to the 
media such that topics of concern in the past, such as child abuse, did not 'benefit' from the same level of pervasiveness as the media today to spread about the panic. According to Jenkins,

"the phenomena of child abuse, serial murder, etc. are scarcely new. What has been different about the last decade is the sheer scale of media coverage concerning the alleged events, and the extent to which the offenses were believed to represent a very widespread threat that could affect almost any family" (1992: 9).

\section{Elements of a Moral Panic}

Discussion of moral panics in the literature involves several basic characteristics. Goode and Ben-Yehuda (1994) identify five main elements: disproportionality, volatility, heightened public concern, hostility, consensus. Though it is important to note that not all authors agree that each element must be present in the identification of a moral panic, these provide a good idea as to what moral panics are and what they entail.

\section{a. Disproportionality}

One of the main elements in identifying a moral panic is the element of disproportionality. Specifically, the fear elicited from the behaviour must be disproportional to the harm that it causes. According to Davis and Stasz, this refers to the 
conception that in actuality, there are more people engaged in the hazardous activity than is reported, and that the damage is "above and beyond that which a realistic appraisal could sustain" (1990: 129). Thompson also added that "(e)vents are more likely to be perceived as fundamental threats and to give rise to moral panics if the society, or some important part of it, is in crisis or experiencing disturbing changes giving rise to stress" (1998: 8). This suggests external factors besides the panic itself may affect the perception of the severity of the situation, which in turn inevitably affects the disproportional character of the reaction.

To assess whether or not a given panic involves disproportionality, it must first be determined 1) What is the targeted fear; and 2) What is the harm that results from the negative behaviours. However, not all scholars believe that it is necessary or even possible to pinpoint a targeted fear or calculate an objective harm. These authors believe that there is no such thing as a "panic" because without an objective dimension, nothing is "ontologically privileged" (Aronson 1984, Kitsuse and Schneider 1989, Woolgar and Pawluch 1985) and therefore disproportionality cannot be calculated. However, as Goode and Ben-Yehuda assert,

"(i)t is only by knowing the empirical nature of a given threat that we are able to determine the degree of disproportionality. The concept of the moral panic rests on disproportionality. If we cannot determine disproportionality, we cannot conclude that a given episode of fear or concern represents a case of moral panic. Again: we can only know disproportionality by assessing threat from existing 
empirical information. But, once again, to repeat: our knowledge of the material world is never definitive, never absolutely certain. We are permitted only degrees of confidence. Still, that may be enough, for some issues, to feel fairly certain that what we say is correct" (1994: 38). For this reason, "(i)n moral panics, the generation and dissemination of figures or numbers is extremely important addicts, deaths, dollars, crimes, victims, injuries, illnesses - and most of the figures cited by moral panic "claims-makers" are wildly exaggerated. Clearly, in locating the moral panic, some measure of objective harm must be taken" (1994: 36).

The question of objectivity is what makes numbers and statistics so vital in the spreading of fear. Numbers and figures seem to have an inherent objective quality about them such that they seem to almost immediately validate a claims-maker's position. The public is rarely interested or given access to the data set or the experimental process that gave way to the statistics. Rather, numbers in and of themselves are taken as objective fact even though as Goode and Ben-Yehuda assert, "(i)n moral panics, the generation and dissemination of figures or numbers is extremely important - addicts, deaths, dollars, crimes, victims, injuries, illnesses - and most of the figures cited by moral panic "claimsmakers" are wildly exaggerated" 1994: (36). However, while numbers can undoubtedly have an impact on the concept of objectivity, it also can be seen that horrific images and embellished verbiage replacing sheer lack of numbers, as in the case of Dine Safe, can be equally or more powerfully convey the sense of panic. In other words, claiming that a certain number of restaurants were found to have bugs may not be as effective as printing 
a larger-than-life detailed picture of a cockroach crawling on a dinner plate on the front page news. In this case, images convey a sense of objectivity or 'proof' of the situation that may have a more lasting impact than numbers.

\section{b. Volatility}

Moral panics often have the quality to erupt suddenly and disappear relatively quickly because they are largely dependent on the fickle interests of the public. As the old adage goes, 'out of sight, out of mind' unless individuals like moral entrepreneurs succeed in propelling public support. Though the fear targeted in the panic may have existed for time and millennia (as these fears are the most facile to target), the large, heightened outburst of public reaction towards behaviours that such fears emanate from are new. For example, in the case of health inspection, while it may not be a "new story" that restaurants occasionally have bugs, the bombardment of the news media and the public outrage that ensued was both sudden and new; as was the interpretation of what certain elements such as bugs and absence of sneeze guards were constructed to symbolize. In one case, the Star mentioned Movenpick, a relatively high-priced establishment in one of its stories alongside mention of a "very scary bakery" that was unlicensed and found to have cats strolling on top of preparation areas. Although it was mentioned that Movenpick charges were the failure to wash dishes in sufficiently heated water and one employee that failed to wear headgear, suddenly this well-known fancy restaurant was lumped into the same story as the aforementioned bakery and minor infractions become linked with serious offences (Toronto Star, March 4, 2000: A28). 
Surely people recognized prior to the exposé that some restaurants do not engage in optimum cleanliness. However, until the "investigative" news serial 'Dirty Dining' came out, most consumers would have simply made note not to patronize such establishments or file a report with Municipal Health rather than go up in arms to lobby the government.

It is conceivable that the media is responsible in large part for the nature of the volatility in moral panics. This is because the media is interested in rapidly disseminating new news in a strong attention-catching manner; thus in essence, volatility is inherently built into the media mechanism. Newspapers normally do not sell if stories are repeated over and over again. Stories must be constantly regenerated with a 'fresh' perspective or at least have the semblance of new findings before it is considered newsworthy. Cribb's 'Dirty Dining' news serial lasted little over one year. This is considerably longer than most news stories, exposes or news serials. It is interesting to ask why the issue of restaurant health inspection as a story, in this case, lasted so long. This seems to suggest that while Goode and Ben-Yehuda are right in claiming that moral panics often erupt suddenly and without warning, they do not often or always fade quickly; and thus are not "similar to a fashion, the fad, and the craze" as the authors suggest (1994: 38-9). Rather, some instances of moral panic may require the government to actually "do something" before they subside. What is also interesting to note is that, given the volatility and the general rapid-disinterest of the public in most news stories, is to investigate why in the particular case of restaurant health inspection that such story resulted in the reformation of municipal legislation while numerous cases of similar 
stories concerning to the city's health and well-being do not. These questions will be addressed in the following chapters.

\section{c. Heightened Concern / Fear}

There must be a certain degree of heightened public concern about the targeted behaviours and the group considered responsible for the behaviours in a moral panic (Goode \& Ben-Yehuda 1994: 33). Similar to the element of disproportionality, the level of concern as well as the objective portrayal of public reaction can be easily contested. Though Goode and Ben-Yehuda argue that this level of concern can be measured in ways such as public opinion polls, public commentary in the form of media attention, proposed legislation, and social movement activity (1994: 33), these quasi-statistical measurements and individualistic accounts can be easily manipulated and misinterpreted. Whereas traditionally, the public reaction in a panic is described as fear, the authors note that the reaction need not be fear per se, but a heightened level of concern (Goode \& Ben-Yehuda 1994: 33). While the authors chose to distinguish 'fear' from 'concern', the chosen term does not effectively capture the mentality of a moral panic. In other words, mere "heightened concern" seems too benign to describe the amount of public response that ensued. Thus fear, defined as a strong aversion towards certain events or behaviours is more accurate in the context of moral panics. In this light, by identifying what it is that the public abhors, we are able to discern what it is that the society values. 


\section{d. Hostility}

Often concomitant with a widespread public fear are feelings of hostility towards the group that is felt to be responsible for the unwanted behaviours. Whether rightly targeted or not, it is necessary to identify an offending group in order to being processes in 'solving' the problem. Furthermore if there is generally some reservation towards those who are seen as "other", those who are portrayed as deviant and harmful to society can be expected to be treated with hostility. Though, not surprisingly because of the term's inherent subjectivity, authors have not specified what degree of hostility is involved in a moral panic Cohen says that such phenomenon entails society's "fundamentally inappropriate" reaction to comparatively minor events (1972: 31). Increased public sensitivity towards the target of moral panic may also lead to stereotyping of individuals such that these groups become coterminous with evil and wrongdoing.

\section{e. Consensus}

Included in Goode and Ben-Yehuda's definition of a moral panic is the element of consensus. According to the authors, there must be widespread agreement that the behaviours targeted in the panic are a threat to society. In their words, "(a)t no exact point are we able to say that a panic exists; however, if the number is insubstantial, clearly, one does not" (1994: 34). It seems logical that an event cannot be deemed a moral panic if only a select few express concern over it. However, it is unclear how many people must be involved for a moral panic to be recognized as such. The relatively 
arbitrary and subjective nature of these elements leaves a lot to personal interpretation. How many are required in a consensus? What is the fear and what is the harm involved in determining disproportionality? What level of concern is required and how do we determine increased hostility? Are words enough, or are actions required? In addressing these questions, it leads one to think: Are there differing degrees of moral panic? Goode and Ben-Yehuda assert that "moral panics come in different sizes - some gripping the vast majority of the members of a given society at a given time, others creating concern only among certain of its groups or categories (1994: 34). This further opens up the concept of the moral panic in a "grab all" of many sociological phenomenon in that they can be large or small, can target many or few. Perhaps this is why in Critcher's view, moral panic "is more of a sociological tool to analyze behaviours and reactions." In his opinion, it is naïve to aim to prove the existence of moral panics, and that "moral panic was not a thing but an abstract concept, a model of a process" (2003: 2). Thus, while it is important to realize that consensus is required in identifying a moral panic, one need not get into the process of calculating how much of an element is needed when one regards 'moral panic' as a sociological tool as opposed to a phenomenon in and of itself.

\section{f. Difference of Opinion}

Again, it must be stressed that some of these elements are debated in the literature. For example, Zatz (1987) does not include consensus as an element of moral panic, and in the case of Hall et. al. (1978), the authors disregard consensus all together in believing that the notion of 'public concern' is entirely concocted by the elite members of society. 
While theorists tend to focus on different elements of moral panics, there is generally agreement on at least two: 1) a heightened level of concern towards the target behaviour; 2) increased hostility towards the targeted group thought to be responsible for such behaviour (Davis and Stasz 1990: 129; Thompson 1998: 9).

While an ideal type exists, for the most part, moral panics remain an enigmawaxing and waning within broad characteristic elements; that become identified with the concept depending on time and context. Consistent with Critcher's (2003) view, this thesis does not focusing on proving whether or not Dine Safe was a moral panic as this stance would not help to further our understanding of the process. Rather, this thesis analyzes the process by which one reporter lead the way to exposing the public to something that he thought needed dire attention, the public outcry that ensued, and the reform of municipal legislation that resulted from such action.

\section{Folk Devils}

According to Thompson, the term 'moral panic' implies that the perceived threat to society is to a sacred or fundamental value. The use of these two words indicates that "the perceived threat is not to something mundane - such as economic output or educational standards - but a threat to the social order itself or an idealized (ideological) conception of some part of it", and as such, the use of "folk devils implies evil and strong feelings of righteousness (Thompson 1998: 8). More specifically, "(a) folk devil is the 
personification of evil" (Goode and Ben-Yehuda 1998: 29), are instantly recognizable, and are "unambiguously unfavorable symbols" (Turner and Surace 1956: 16-20).

The concept of "folk devil" is taken from Stanley Cohen (1972). It addresses the fact that when a moral panic arises, an individual or group is inevitably targeted as the 'evil doer(s)' responsible for the negative behaviours that caused the panic. The use of the word "folk" seems to suggest the idea that targeting of these characters may not be the objective, and that their characterization may be real, imagined, or sensationalized. In turn, the identification of a target group is important in quelling the public's fear because it helps to provide a platform to which they can lobby governments and institutions to "do something" about the perceived problem. It must be stressed that this target is not always necessarily rational, but may stem from misguided beliefs that drive selfpurported goals (Goode \& Ben-Yehuda 1994: 3). In such instances, what seems important is that something is being done about the situation, and some group or some individual is held accountable. In the case of restaurant grading, the panic began with one single story published in the Toronto Star targeted one owner of one Indian restaurant, but quickly the folk devil spread from targeting that individual owner as deviant to something commonplace, from one shoddy ethnic restaurant to more varied establishments, such that all restaurants in the Greater Toronto Area were thought to need strengthened legislation. In the words of Goode and Ben-Yehuda, " $(t)$ he moral panic, then, is characterized by the feeling, held by a substantial number of the members of a given society, that evildoers pose a threat to the society and to the moral order as a consequence of their behavior" and, therefore, "something should be done" about them 
and their behavior (1994: 31). A major focus of that 'something' typically entails strengthening the social control apparatus of the society such as tougher or renewed rules, more intense public hostility and condemnation, more laws, and stronger punishments.

The media involvement in rooting out folk devils can be extremely powerful because it has the capability to selectively present ideas or emphasize 'newsworthy' elements of a story. Thus, though the public may be varied, it is often considered as a hegemonic group. In turn, if this group accepts the newsworthiness of the story and importance of the issues presented it is facile to target certain groups in an "us-them" dynamic. In the case of restaurant inspection, once certain restaurants and owners were targeted as the folk devil in the city's Dirty Dining problem, it became difficult for the public to forgive or forget the graphic images of bugs and rats printed in the newspapers. Such infestations are not realized by the public to be sensationalistic or untrue, but become a representative case for the restaurant, and for restaurants in general. As Goode and Ben-Yehuda note, once folk devils have been identified, "from then on, all mention of representatives of the new category revolves around their central, and exclusively negative, features" (1994: 28-9).

\section{Moral Entrepreneurs}

Moral entrepreneurs are individuals who believe that a certain section of society is not being punished severely enough for engaging in behaviours that outright harm others and act upon it to change the situation for the better (Good \& Ben-Yehuda 1994: 80). 
There may be a myriad of reasons why one would feel driven to lobby against such behaviours. Some may be legitimate, some may not. Some reasons may have the public interests in mind, while others may not. Whether the moral entrepreneur genuinely has a selfish incentive in mind, the success of the propagation of the moral panic is directly reliant on the semblance that the intention for such propagation is entirely in the public good (Sinclair 1962: 126).

Becker's conception of the moral entrepreneur includes two different personalities: the rule creator and the rule enforcer. The former is dissatisfied with the current state of the law and is impassioned to work towards lobbying for harsher penalties towards those who he believes are abhorrently evil. The latter is not as concerned with changing laws, but more focused on upholding the changed rules and is only interested insomuch as it affects his or her livelihood as a profession (Becker 1963: 147-8, 156). However, these two categories of moral entrepreneurs do not seem to be helpful since law-makers and law-enforcers go hand in hand such that it is difficult to imagine them as separate entities. True moral entrepreneurs act upon targeted groups because they fervently believe that there is something wrong and are determined to bring about change in the legal system to deal with it. On the other hand, law-enforcers, given their job, do not have the authority to punish individuals that lay outside government policies and when morally offended by certain groups' behaviours, must revert back as a common citizen to lobby for change.

Howard Becker's (1963) description of a moral entrepreneur as a law-maker may also be outdated as private citizens seem to become increasingly empowered to lobby for 
change. His interpretation coincides with Hall et. al's (1978) 'elite engineered' model of moral panics which asserts that public fears and concerns are no more than what lawmakers construct for them. In the case of Toronto's restaurant health inspection, a private citizen (albeit a reporter) was responsible for putting pressure on the government to change the municipal law. It seems as though in many cases, private citizens are more powerful than the government, since politicians are often at the mercy of public interests. The next section will examine how Toronto Star reporter Robert Cribb, as a moral entrepreneur, almost single-handedly garnered enough public outrage and support for the government to listen to his insistence that the then-existing restaurant health inspection practices and public disclosure methods had to change. In this light, it seems that the Interest Group Theory is more applicable, whereby it is believed that interest groups and private individuals are the ones that drive change and that elites take a secondary role in the creation of panics (Gusfield 1963, Jenkins 1992, Goode \& Ben-Yehuda 1994: 139).

\section{Moral Panics and the Media}

The media has a very large role in the dissemination of moral panics as it is the primary form of mass communication in contemporary society. As Thompson rightly noted, the "media is fertile ground for claims-makers - those who wish to make a claim on public opinion and public authorities for attention and resources" (1998: 29). The way in which information is gathered, conveyed, and disseminated has a direct and powerful effect on the way in which is it received. Though some may be aware of the media's farreaching influence, few are diligently cautious about evaluating every piece of 
information that they are bombarded with. Further, the reactions and personal anecdotes that are often added in a newspaper in the Letters section, or the comment talk-back sessions on the news make stories much more believable and seemingly less exaggerated when other citizens write or call in to agree and provide "real examples". These examples may not be realized as anomalies, and the more "severe" cases would be more remembered and repeated until they seem like case examples.

Not only does the media help moral entrepreneurs to spread their claims, but the media itself often goes above and beyond reporting 'facts' to include personal and selective accounts of the situation which undoubtedly have a role in spreading a moral panic. Stanley Cohen recognized in his account of the seaside fights between the Mods and Rockers in 1960s Britain that the media played a crucial role in creating a moral panic by using exaggerated language, distorting and exaggerating the events, overstating its seriousness, stereotyping the individuals involved, and offering unfounded gossip as truths (1972: 31-8). Such "over-reporting" of the events resulted in heightened public concern towards the rapid degeneration of the days' youth nationwide as well as overseas.

As a panic may play on existing fears, it also uses fear to disseminate and promote its stories. The media and those who are interested in the cause are quick to make assumptions and linkages between the events that happened, what implications they cause and often what that means about 'society today'. For example, in Cohen's (1972) example of the Mods and Rockers, the incident was a group of unruly teenagers that got out of hand. The media was quick to interpret this almost commonplace incident as 
indicative of the downward spiral of youth culture, or the emergence of a new kind of youth culture dominated by gangs, violence, and irreverence for people, property, and the law. However, it must be stressed that the media should not be seen as an evil conglomerate that goes about spreading sensationalism in the interest of selling more papers. It is not the case that the media has sole possession in dictating public concern. Though the public can be seriously influenced by the media, the media in turn would not be as successful in spreading a panic if the fears did not resonate with the public. In other words, "( $t$ )he media's exaggerated attention must touch something of a responsive chord in the general public" (Goode \& Ben-Yehuda 1994: 26). Again, the targeted events in a moral panic are not as important as what they symbolize. What they represent is what society holds dear. Whether or not the media influences these conceptions, a moral panic is only successful insofar as it can be shown that something that society values is at stake and certain individuals, or folk devils, can be held accountable.

While Cohen (1972) addressed the issue of the media when the theory took off, it seems as though 'media' and 'moral panic' are increasingly becoming synonymous. In many ways, the media uses sensationalism to propagate ideas, and because of its farreaching quality it is the main way that moral panics spread. With the pervasive nature of media and communication technologies today, it is no surprise that the study of moral panics is becoming more intertwined with the study of the media (eg. Critcher 2003, Springhall 1998). John Springhall even formally includes the media in his definition of a moral panic. In his study on moral panics and youth popular culture, he asserts that “"(m)oral panic' occurs when the official or press reaction to a deviant social or cultural 
phenomenon is 'out of all proportion' to the actual threat offered. It implies that public concern is in excess of what is appropriate if concern were directly proportional to objective harm" (1998: 4-5).

The next chapter considers how the media plays a critical role in heightening public concern towards what is perceived as the lack of adequate measures to ensure that restaurant patrons in the Greater Toronto Area dined in a manner consistent with municipal health regulations at the time. The Toronto Star provided the main source of the scare, with reporter Robert Cribb as the primary moral entrepreneur leading the oneyear movement that eventually led to a change in municipal law that required every restaurant owner to display placards in their front windows that publicizes the results of their latest health inspection for all patrons and passer-bys to see. 


\section{Chapter 2}

\section{Part I: The Moral Entrepreneur and the Role of Media The Moral Entrepreneur}

On February 19, 2000, Toronto Star staff reporter Robert Cribb made it clear to the citizens of Toronto that a large number of the City's eating establishments were shoddily run as a direct result of irresponsible restaurateurs who were consistently violating health legislation as a result of the existing unsatisfactory regulatory system. According to 1998 and 1999 inspection data, only 11 of the old city of Toronto's 6,895 restaurants were closed down despite numerous critical health infractions (Toronto Star, February 19, 2000: A1, A13).

City's health inspection system for restaurants a menu of failure and inaction, a Star investigation reveals blasted the front-page headline (Toronto Star, February 19, 2000: A1, A13). Though the article started by describing one cockroach-infested Indian restaurant located then in a trendy intersection in the downtown core, Cribb quickly noted that this shoddy restaurant was one of many that remained open despite obvious health infractions.

Toronto inspection data from the past two years (1998-99), obtained for the first time by The Saturday Star, show more than 750 restaurants in the old city ${ }^{2}$ received at least one citation for a "critical" food safety problem - the most

\footnotetext{
${ }^{2}$ The new City of Toronto consists of an amalgamation of seven municipal governments to what is now called the Greater Toronto Area (GTA) and was created on January 1, 1998.
} 
serious kind of infraction, which can lead to food poisoning and other food-borne illnesses.

Dozens of these restaurants show histories of food safety problems, but are still permitted to serve food to unwitting diners without penalty or public knowledge. (Toronto Star Feb. 19, 2000: A1)

In an interview with Toronto Star staff reporter Robert Cribb (June 3, 2005), he disclosed that his 'Dirty Dining' series originated out of his concern regarding the lack of governmental transparency in the access of information granted to citizens. After dining at a local "hole in the wall" Italian-Canadian restaurant, Cribb became violently ill from food poisoning. As a citizen, he was then "curious....out of personal edification" to see the restaurant's inspection history but "after going up the chain of command, (he) thought it must be a mistake" when he was told the information was inaccessible and was given the run-around by various departments. When he asked the Toronto government for these records, the City originally quoted him a cost of $\$ 148,000$ to obtain the desired information, an amount virtually impossible for the average citizen to pay, making the act of gathering this information possible but improbable. After much haggling and a diligent six-month effort, Cribb was able to obtain inspection data for the 6,895 restaurants in the old city of Toronto (Toronto Star, February 20, 2000: A1, A8) for a discounted price of $\$ 350$, an amount which he believed was still unfair to obtain information that should be free. 
The incident angered Cribb. Citizens could not realistically obtain access to health inspection records and therefore could not arm themselves with necessary information to protect themselves from possible food poisoning and food borne illnesses. Even the most diligent person would have little chance of success considering the amount of money and effort required, if a well-connected staff reporter for the City's largest circulating newspaper had such difficulty. It was wrong that restaurateurs were getting away serving customers dirty food that made them sick. In his words,

Dozens of these restaurants show histories of food safety problems, but are still permitted to serve food to unwitting diners without penalty of public knowledge.

Unlike food outlets in cities such as Los Angeles, Chicago or Atlanta, which are required by law to post inspection reports, Toronto restaurants are off the hook. (Toronto Star, February 19, 2000: A1)

With daily articles such as Many cities release restaurant reports; why can't Toronto (Toronto Star, February 20, 2000: A1, A8), Shoddy eateries to be named this week (February 23, 2000: A1, A19), 'Media spotlight' forces move (Toronto Star, March 2, 2000: A1, A22), and Province-wide eatery ratings sought (Toronto Star, April 15, 2000: A8) it was apparent that Robert Cribb felt that the great injustice of 'dirty dining' in Toronto must be stopped. His offered solution was to increase transparency with the posting of restaurant health inspection results modeled after similar systems in cities like Chicago and Los Angeles (Toronto Star, February 20, 2000: A1). 


\section{The Moral Entrepreneur's Intent}

As Sinclair noted, the intention of the moral entrepreneur is not always evident, and what intent is vocalized may just bear the needed qualities of public good and servitude that necessitates the public spread of concern (Sinclair 1962: 126). What seemed to trigger Cribb's anger to start up the project of 'Dirty Dining' was not merely experiencing severe food poisoning, though the incident did jumpstart the campaign. Rather, he felt it was wrong that while the law guarantees the rights of citizens to "know", the catch is that the price for this information made it virtually impossible for the average citizen to obtain.

Robert Cribb noted the difficulty not only in accessing restaurant inspection records, but accessing government information in general. Whereas reports of food poisonings existed in the past, no other reporter was able to put pressure on the city because these incidences were easily brushed off as sporadic anecdotal cases. With the release of restaurant inspection records, Cribb was able to reveal objective evidence of numbers and trends that substantiated his arguments. This information was the key to success as officials were no longer able to ignore the existing quality of restaurant health inspection practices and directly led to the change in law towards today's Public Health Food Premises Inspection and Disclosure System (commonly known as DineSafe) (June 3,20005 interview). As a reporter, it is conceivable that full exposure to all types of government information would be beneficial in facilitating his job. This coincides with his repeated emphasis on the problem of the lack of government transparency. However, lack of transparency in itself would not have been sufficient to initiate change because 
within the moral panic framework, it would not appeal enough to public concern to incite immediate attention and change. The moral panic requires a stronger push, as public fear or anxiety determines the success of its propagation. To achieve the desired ends, the problem has to be presented in a way that both excites strong interest and addresses public, rather than individual concerns. Altheide noted,

"Mass-mediated problems are oriented to be everyone's problems, whether as direct or potential experience or as sympathetic audience members. The prevailing media logic is to establish a relationship between the viewer and the format and the story form." (2002: 49)

Cribb may have been concerned with the lack of government transparency (arguably a noble cause), but the public may not have shared the same concerns. Certainly government officials would have no incentive to spend valuable time and effort in revamping policy to increase levels of transparency. Such measures would be costly and other issues were considered more 'important'. The problem as constructed by the media to address public concern was not first and foremost a transparency issue. Though the perception of the problem differed, increased governmental transparency became the solution.

February $19^{\text {th }}, 2000$ marked the beginning of Robert Cribb's award-winning investigative news series entitled 'Dirty Dining' that culminated into Toronto's current 
'DineSafe' program. The article featured prominently on the front page of the Toronto Star, occupying roughly one-quarter of the space. It began:

Haider Khan is defiant.

The pile of inspection documents sitting in front of him contains, a string of reported health code violations against his Rajputs restaurant on Bloor St. W. near Spadina, including food temperature problems, unwashed hands, mice droppings and cockroaches. (Toronto Star, February 19, 2000: A1, A8).

This article marked the beginning of the Cribb's year-long crusade to change the city's restaurant health inspection practices. Articles in this series appeared daily for the first few months and were also supplemented by numerous related articles written by other reporters, editor's notes, and written letters submitted by readers that remained as a constant reminder several times a week thereafter. The newspaper provided a constant update of restaurants that were found to violate health standards, anywhere from failure to provide sneeze guards and inadequate hand washing to severe mice and cockroach infestations. By using information eventually obtained from government records, Cribb substantiated his articles with 'facts' showing that the Toronto Public Health was not carrying out the minimum number of restaurant inspections required and that offending restaurants were not being adequately punished to deter unclean food preparation 
practices. The discourse and graphics accompanying pictures made it obvious that this was an atrocity that could not afford to be overlooked.

\section{The Media plays a Constitutive Role}

Stanley Cohen (1972) in the case of the Mods and Rockers addressed the role of the media in his first account of a moral panic. The media played a central role in causing widespread concern over the seaside fights by stereotyping the individuals involved, drawing strong and direct inferences between the events and the degradation of society, and exaggerating and over-reporting the events. As Critcher argued, “(m)odern moral panics are unthinkable without the media, though medieval witch trials managed without them" (2003: 131). The media and 'moral panic' are becoming increasingly difficult to tease apart, as "(s)ocial reality is experienced through language, communication and imagery. Social meanings and social differences are inextricably tied up with representation." (McRobbie and Thornton 1995: 570). Since moral panic requires widespread public concern (Goode and Ben-Yehuda 1992) and such information can only effectively be distributed by the media ${ }^{3}$, it can be confidently concluded that the media plays a necessary and constitutive element in the study of moral panic today.

By nature, the media has a tendency to exaggerate. To say that the news media creates news, though a common idea is not accurate. The role of the news is to reflect daily happenstances that typically appeal to larger audiences. The 'creativity' comes

\footnotetext{
${ }^{3}$ where 'word of mouth' would not adequately spread information as far or as quickly as media
} 
from the careful selection of events deemed as newsworthy, and the subsequent analysis of the events that emphasize its newsworthiness. As such, the news is then able to select from its chosen newsworthy stories ones that seem to be 'most newsworthy', that is those most likely to incite public interest and concern to push through the moral panic framework. This is further complicated by the fact that a newspaper's existence relies almost solely on the number of papers sold, therein identifying one of the fundamental conflicts of news reporting: the act of reporting 'objective' fact despite subjective filtration of events is confounded by the driving force of the capitalist nature of media. The tendency of media to exaggerate, coupled with the discretionary power of the news to report events also makes it a perfect vessel of the moral panic to birth, brew, and bubble over.

The assertion that news creates moral panics understandably offends journalists. To suggest this treads too closely to the image of tabloid news, effectively questioning the semblance of unbiased objectivity respectable news media tries hard to preserve. Nevertheless, there is truth to the claim that news media in and of itself is not capable of creating a moral panic. As Cribb (June 3, 2005 interview) asserted, a large role is accorded to the citizens. It is the people's interest that decides whether or not the problem at stake requires attention. The news serves it, presenting it deliciously on a plate. Whether or not the public eat depends on the nature of what is served, the presentation, and the timing. 


\section{Part II: The Panic and the Process The Problem}

Problems may seem obvious, but they are not always objective. Certain events and situations can be constructed as problematic purely by personal bias and strong assertive rhetoric. In and of itself, the failure of the city to provide inspection records may not be a problem, or in the least, not as large a problem that deserved such intense and prolonged public attention. However, in the moral panic framework, it takes a moral entrepreneur to advocate it as such. Effectively, the time, attention, and strength of influence by the moral entrepreneur directly relates to the success of the panic. Hunt noted that, "(p)roblematization thus concerns the ways in which issues become the focus of concern, or in an earlier sociological tradition, how and in what way 'social problems' are generated" (Hunt 2003: 173). The way in which events and happenstances are construed and the adverse effects argued is pivotal and can determine the success of a panic.

Some authors believe that citizens are virtually powerless when it comes to the selection and presentation of news stories. As Ericson and colleagues noted:

"Journalism is concerned primarily with communications among elite authorized knowers. Journalists are oriented to the audience of regular sources-as-reporters who join them in the hermeneutic circle. Everyone else is left to watch, to listen to, or read the distant representations that form this symbolic spectacle." (Ericson et al. 1987: 351) 
Other authors note the considerable power the mass media has to manipulate public opinion (Rocheron and Linné 1989: 417) or even construct it (Astroff and Nyberg 1992: 10) in moral panics. However, this may not be a problem in itself. As Goode and Ben-Yehuda noted, there is more than one model of the moral panic. The manipulation of public opinion may fall into the elite-engineered model (Goode and Ben-Yehuda 1994: 135-8) which believes that they are created to forward the interests of the elite. However, irrespective of Cribb's intent to reduce government transparency, it was evident that the public readership had a different concern.

After obtaining the requested documents, it was found that in 1999 only $46 \%$ of the required inspections were made. Only 11 restaurants were fined in the two years (with an average of $\$ 45$ a fine) despite critical violations like mice and cockroach infestations in many more restaurants. In 1999, health inspectors noted 10 critical violations over 4 different inspections at the Saigon Flower Restaurant but the restaurant was not given any penalties. Abdelraouf Ali, owner of the Khartoom Falafel House received no penalty for numerous violations including improper food temperatures, lack of hand washing, lack of thermometers and liquid soap, and an overall "poor hygiene" of kitchen staff. No penalty was given despite 10 critical food violations at the Garlic Pepper Szechuan Cuisine (Toronto Star, February 20, 2000: A1). Such is the type of 'objective' evidence that Cribb was able to present. While these figures would be different to concoct, the semiotics behind what they mean is open to interpretation. Thus, while it may be true that the 'elite' can use such information to their advantage, whether 
the public agree with the interpretation depends on the interest expressed. Consequently, it is the level of public interest that determines the focus of news stories.

The Star showed that an unacceptable number of eateries in the city were allowed to frequently and habitually violate health codes. The old city of Toronto had only 27 health inspectors whose responsibilities included inspecting the city's restaurants up to three times a year, as well as other duties like rabies control and water testing (Toronto Star, February 22, 2000: A1). Restaurants were taking their patron's money and 'getting away with' unclean practices and serving dirty food.

To the consumer the issue was not food poisoning. The problem, as Cribb put it so succinctly, was simply that "no one wants rat shit in their food" (Cribb interview June $3,2005)$ or even the thought of ingesting 'dirty' food. Food poisoning and food-borne illnesses was just part of the rhetoric and statistics about food poisoning served to justify irrational fears. Showing the shoddy conditions of restaurants helped to support the distinct possibility that readers might go into a restaurant, whether Movenpick or their local 'hole in the wall' that they just might unknowingly ingest something as horrible as vermin fecal matter.

\section{Creation of the folk devil}

In every moral panic a folk devil emerges. When a problem is presented, we take solace in identifying who is to be blamed so subsequent punishment and rectification can 
begin. This involves labeling an individual or group that is responsible for the targeted actions and justifies the punishing of the offenders by perpetually evoking images reinforcing the wrongdoing. In Cohen's words,

"This imagery is an integral part of the identification process: the labels are not invented after the deviation. The labelers - and the ones I have concentrated on are the mass media - have a ready-made stock of images to draw upon. Once the initial identification has taken place, the labels are further elaborated: the drug addict, for example, may be fitted into the mythology of the dope fiend and seen to be dirty, degenerate, lazy and untrustworthy. The primary label, in other words, evokes secondary images, some of which are purely descriptive, some of which contain explicit moral judgments and some of which contain prescriptions about how to handle the behaviour." (1972: 74)

The government officials and Toronto Public Health were initially presented as negligent to the wellbeing of its citizens. City's health inspection system for restaurants a

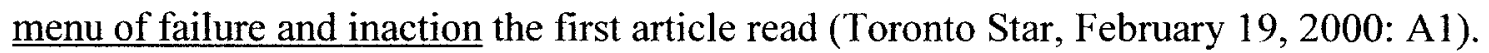
However, quick-thinking Dr. Sheela Basrur, the city's medical officer of health quickly admitted fault of the Toronte Public Health and sided with citizens to capitalize on previous unsuccessful requests for more funding from the city. She also acknowledged the accuracy of the articles saying it "provides a fair portrait of the food safety program in Toronto. There are faults in the system at many levels." (Toronto Star, February 21, 2000: A1) Cribb noted that he was surprised at this move as officials rarely admitted 
fault, but in this case Basrur was wise to use 'Dirty Dining' to her advantage. Thenmayor Mel Lastman responded with lightning speed. Just two days after the publication of the first 'Dirty Dining' article, the front page read Lastman orders blitz on Dirty Dining, quoting:

"Restaurants have at least one week to clean up their act and if they don't do it by March 1, we'll close them down....If it means brining all the inspectors to downtown Toronto for a week or two weeks we're going to do a sweep...If we find cockroaches, if we find mice, we find droppings, they're closed... until they clean up their act." (Toronto Star, February 21, 2000: A1)

When it was apparent that officials were taking action, it was difficult to continue pinning them as the bad guys, even if they briefly feigned ignorance or helplessness in the situation. The discourse quickly shifted towards targeting heartless restaurateurs who were more concerned with maximizing profits than bothering to keep premises and food preparation practices clean. Health inspectors fail 53 restaurants the front page read a week later announcing the first closure of Mel Lastman's blitz, Beemah, an Indian restaurant after inspections noted dirty floors, walls, and ceilings as well as an active infestation of mice. Though owner Raja Visvanathan was said to be out of the country at the time, an employee offered,

"The whole area is like that," said the man, who asked not to be identified. "These are old buildings. We have the traps and the glue and we get in pest 
control once or twice a month. But if we get some mice, what can we do?"

(February 26, 2000: A27)

A man answering the phone at $\mathrm{ABC}$ Breadco, a bakery and bread distributor closed after inspectors found three cats walking through garbage and in dough and bread preparation areas responded to questions by saying "sh-happens." (March 2, 2000: A1). The manager of the 110-year old Isabella Hotel restaurant closed by inspectors after found evidence of a mice infestation said, "The mice and rats have to go somewhere in the winter." (March 7, 2000: A1, B1)

With quotes like these, the newspaper emphasized the apathy of restaurant owners and workers and by repeated comments sympathizing with consumers and statement denouncing the conditions of Toronto restaurants, authorities effectively established the image of the careless, unethical restaurant owner. This facilitated the shift in opinion, whereby the restaurateurs became the folk devils of the panic.

\section{The Moral Dilemma}

In every moral panic the moral element must be addressed. Whereas some authors have identified past events such as witch crazes, religious fundamentalist endeavors, child abductions, Prohibition, and the War on Drugs as moral panics, there seems to be some ambiguity in some identifications where the 'moral' element is not 
overt. Without delving into a philosophical debate on the nature of morality, some issues seem to be more overtly 'moral' than others. More recent debates on abortion, for example, are deeply rooted in arguments of what is (morally) right, with many arguments against women's free choice to abort as being immoral, unjust, unethical and condemnation often stemming from religious axiom.

The movement of contemporary law and society from punishing citizens based on person or character towards the punishing of detrimental actions has a bearing on moral panics today precisely because of our hesitation in legal doctrine to condemn states of being. Alongside secularization, what is considered moral or immoral is both detached from the individual as well as detached from religious beliefs with regards to law. Thus, punishment of crimes are carried out because of a violation of law, which is generally enacted with rhetoric of maintaining the 'Greater Good' as opposed to an attempt to prevent the moral degeneration of society. The fervour and strength of public reaction against even the most hardened of criminals erupt because his actions are seen as 'wrong' because they may provide a risk of harm to society, and not necessarily 'immoral'. As Hunt argued, there has been a shift in moral regulation over the last century from condemnation of distinctly wrong or immoral acts towards less precise classifications (Hunt 1999). He observes that

"Increasingly, morality has come to function through proxies, not in its own voice, but in and through other discursive forms, the two most important and closely related being the discourses of 'harm' and 'risk."' (2003:166). 
Therefore, it is important to take into account the contemporary equivalent of 'morality' when analyzing the moral value in contemporary moral panics and recognize that "Projects articulated and justified in terms of 'risk' that invoke 'harm' are frequently also projects of moral regulation" (Hunt 2003: 167).

Often alongside identification of wrongdoing is the idea that "Something must be done". This "something" is usually an argument for creation of new laws or strengthening punitive measures for existing laws. A common idea in the move towards strengthening legislation was effectively expressed by one consumer who said, "If the chance of getting fined is so small and being closed down is nil, they're going to keep doing it" (February 21, 2000). Implicit in this mentality was the opinion that without public disclosure or stricter penalties restaurateurs would have no qualms about continuing to serve dirty food, even if 'experts' claimed that thousands of people have food poisoning without actually knowing, 2.2 million Canadians contract foodborne illness every year, and up to 3,500 cases result in hospitalization and 500 lead to death (Toronto Star, February 19, 2000: A1).

As mentioned earlier, the Toronto Star showed that restaurant owners and staffers were fully aware of mice, cockroaches, and various other critical health violations. It did not seem to faze them that they were receiving money for serving dirty food with mice droppings as such vermin as they simply shrugged it off that it was unavoidable in food establishments. Sometimes the changes requested by health inspectors required renovation costs (Toronto Star, March 7, 2000: B1-B2). While restaurant owners 
claimed they wanted to be compliant, they said the costs would be too much to afford and that even closing the shop to renovate would be beyond their financial capabilities (Toronto Star, March 7, 2000: A1; Toronto Star, March 11, 2000: A9). Others tried to shift the blame by noting that they bought the restaurant in such condition without being aware of mice and tried to skirt responsibility (Toronto Star, March 11, 2000: A9). Some took off altogether in "runaway cases" whereby owners of charged restaurants simply left the location and applied for a new license under a different restaurant name instead of cleaning up (Toronto Star, April 5, 2000: B4). One restaurateur even made reference to bribery, noting that slipping the health inspector $\$ 50$ per month was enough to "overcome" mice infestations (Toronto Star, March 14, 2000: B2). Although renovations may have been costly, it was noted that even restaurant owners who had not been targeted were guilty because while food handling education was shown to be beneficial in minimizing food borne illnesses, only 500 people a year took Toronto Public Health's voluntary food handling certificate program that started at $\$ 25$ (Toronto Star, Feb 20 , 2000: A1). According to Ericson et. al., "Morality as a process involves the use of evaluative dualisms (e.g. good-evil, brave-timid, free-enslaved) to assess objects" (Ericson et al. 1987: 7). Such examples make it seem that not only did these owners recognize the problems and know how to go about fixing them, they just did not place enough value on the public's wellbeing to carry out the necessary changes. By showing that restaurateurs knowingly engaged in actions that could seriously affect the health of unknowing customers, their morality was brought into question. 


\section{The Fear}

Hunt notes the blurring between 'fear' and 'anxiety' by providing that,

"Anxiety is a psychic condition of heightened sensitivity to some perceived threat, risk, peril, or danger. A distinction between anxiety and fear seems both possible and attractive, but it is not ultimately sustainable. One possibility is to define fear as an immediate response to danger, while anxiety is a generalized non-immediate apprehension." (2003: 174).

Perhaps in this sense, a more accurate account of what readers felt was a 'heightened sensitivity' towards eating out. They may have been extra cautious and more cognizant of signs that the establishments they did choose to eat at were 'clean'. Readers wrote into the Toronto Star offering tips and suggestions on how to spot dirty offenders. Some urged other readers to take a careful look at the restaurant surroundings, and to check out washrooms. They noted that if the environment of the restaurant was 'dirty', chances are, so was the kitchen (Letters, Toronto Star, March 3, 2000: A27). One woman suggested bringing your own mints, as mint bowls in restaurants could be filled with harmful bacteria. Some expressed peripheral concerns, showing hyper-sensitivity to other situations that could be considered as "dirty dining". One wrote about concerns she had for the "picnic-style" eating that teachers allowed in elementary schools (Letters, Toronto Star, March 19, 2000: A27). A man questioned the cleanliness of beer factories, suggesting that breweries could be heavily infested with mice (Letters, Toronto Star, March 9, 2000: A31). It is evident from these examples that the public had increased 
attention towards food practices and what they felt was 'unclean'. Claims that may have gone unnoticed or brushed off as paranoid before the 'Dirty Dining' series were now seen as acts of warning made by diligent, responsible citizens in the fight against dirty food.

Whether it was actually fear or danger could be arguable. The newspapers pushed for immediate action, trying to draw attention towards incidents of food poisoning, though severe forms of food poisoning did not seem imminent. However, it is important to note that while the public did experience heightened sensitivity, the discourse Cribb and the papers used was a discourse of fear. Though he was careful not to directly link incidents of food poisoning with specific restaurants (interview Cribb, June 3, 2000), the rhetoric and careful usage of interviews with health officials strongly suggested that citizens should be fearful of ingested contaminated with food, not only because it is unappetizing and aversive, but because people are disabled, hospitalized, and die from contaminated food. Suddenly food handlers who do not wash their hand for a full minute, the absence of sneeze guards, or a crack in the ceiling gets thrown in with infestation and spoiled meats as red flags citizens should be wary of for the sake of their own lives. As Athleide rightly noted, "Directing fear in a society is tantamount to controlling that society" (2002: 17). In the case of moral panic, there might be a blurred sense of fear and anxiety, as the way feelings are portrayed as well as felt. Later, generalized discourses of fear are readily used in news media,

"The explicit use of the word fear and its multiple derivatives and meanings pervade public discourse. As noted previously, this occurs as part of the routine 
news process as claims makers learn to cast their statements in a context of fear relationships." (Altheide 2002: 54).

Though it is understandable that fear is experienced on a continuum, with heightened anxiety on the lower spectrum, and full-blown fear at the other, the aim is to always maximize stimulation of fear such to create an argument for immediate action. With the selective publication of severe cases generating fear, coupled with elements of objectivity from statistics and interviews for legitimisation, and constantly asserting the desired solution, Cribb was well on his way towards achieving his goal of increased disclosure.

Moral panic does not exist naturally. It is a socially-constructed label applied to certain phenomena to explain and examine social reactions to carefully engineered interpretation of events. Fears may be inherent to the human condition. Problems and issues may always exist. But the moral panic must be constructed through interpretation and reaction. Thus, the same issues and the same fears can appear again and again but without careful construction by a moral entrepreneur, these fears and issues will remain merely as fears and issues. Moral panics build on fear, those of which inherent fear is the best fodder for spreading panic. Specifically, we have wired aversion towards rats and cockroaches. The thought that these vermin could be crawling around eating establishments or ingesting their droppings through contaminated food is incontestably revolting. This is further exacerbated by claims that these and other high-risk critical violations are common behind kitchen doors as consumers play a losing game of Russian 
Roulette when dining out. However, though fear may be socially constructed, it does not mean that it is not perceived as real or does not have real consequences (Altheide 1995 in Altheide 2002: 55). Within two days, approximately 3,800 people responded the initial two-day 'Dirty Dining' series. The overwhelming majority of respondents agreed that the city needed to get tougher on offending restaurants and that restaurant inspection information should be readily made available to the public. ${ }^{4}$ Approximately 600 callers left comments with Starphone expressing disgust, outrage and fear of restaurant cleanliness. One caller claimed that she came "awfully close to dying" after eating in a .Toronto restaurant (Toronto Star, February 21, 2000: A1).

Stories and anecdotes were often extreme. An anonymous caller told the Star readers of a restaurant that held the owner's deceased dog in the kitchen's freezer waiting for the winter frost to subside so it could be buried (Toronto Star, March 11, 2000: K5). On the front page, a 42-year-old dentist and mother of two said that she didn't go to restaurants anymore after eating a meal in a downtown Toronto restaurant that she claimed nearly ruined her liver from a near-fatal case of Hepatitis A. Even though the incident happened four years previously, she still does not sleep well or feel healthy and could not work full-time. "I'm going to be physically disabled for the rest of my life," she said. "It's had a horrendous impact on my life. My life has shrunken into nothing." (Toronto Star, February 21, 2000: A1).

\footnotetext{
${ }^{4}$ The first question was asked and 1650 answered YES to The Star's poll asking whether the city should get tougher on restaurants that habitually breached health codes while 10 said NO. In response to the second question asked the day after, 2000 callers said YES and 21 said NO. (The Toronto Star, Feb 21, 2000)
} 
- The idea that one could innocently go into a seemingly clean restaurant, eat seemingly clean food and then go home and be physically disabled for life, though unfortunate, is no doubt highly unlikely. What could cause the level of paranoia? Did people realize that the extremity of these stories? Surely if it was just the aversion to food poisoning things wouldn't have been so extreme. Few people were aware of the rates of food poisoning, as they were only mentioned briefly in the 'Dirty Dining' series. The over-reactions may have been partly attributed to the sensationalistic quality of the news, as the most extreme stories are generally published. However, as extreme as some of these anecdotes may be, they were not contested as they fell into the general overarching fear of the unknown. It was not questioned whether or not a dog could be in the freezer. The emphasis was not on the unlikelihood or the rarity of these cases. Rather, once the framework for 'Dirty Dining' was set, these stories were accepted into the realm of possibility. Frozen dogs, live rats, mice, cockroaches, live cats running through the kitchen, all these could happen because it was shown that the City's existing inspection system and non-existent disclosure system did not and could not prove otherwise. As Critcher noted with the UK salmonella egg-scare, "once established in the discourse of the media, it persisted autonomously within that discourse, going on and on at an increased pitch independent of the factual unfolding of the matter. The great egg scare was not a medical phenomenon, not an epidemic; it was a construct of discourse, a formation and transformation of ideas in the public language of the newspapers and television" (2003: 171-2). As with the UK example, once the news established, everything from the lack of headgear, to the most extreme cases fit into the inferential structure' (Lang and Lang 1955, Halloran et. al. 1970) or what Watney described as an 
'overhead narrative' (Watney 1988). Once the issue was accepted by the public, the underlying assumption becomes that anything and everything can go on behind those kitchen doors. If some restaurants were found to get away with these atrocities, suspicions of all restaurants were automatically heightened. Suspicions were confirmed by restaurant workers (who often chose to hide their identity), pest control workers, and sometimes owners themselves. One owner said of other restaurants, "It's shocking what I've seen in some kitchens in this city. One place had 200 cockroaches in a box of biscotti they serve to people. I'd gladly welcome a posting system that brought the standards up." (Toronto Star, February 22, 2000: A1). Even the mayor did his part to stir up public reaction with claims like, "(The Star investigation) made me sick," Lastman said. "I think it's made everybody sick. You figure you're eating a piece of pie or steak or something and you're eating rat droppings....This is not acceptable at all" (Toronto Star, February 22: A19). And once this inferential structure was established, soon questions about food in other contexts began to be posed. Letters poured in from readers such as What about legions of mice in beer brewing plants? (Letters, Toronto Star, March 9, 2000), There's a fly in my soup - or is that a cockroach?; Something smells fishy; Let's hit restaurants where it hurts; Public must demand improvement (Letters, Toronto Star, February 26, 2000: K7). As Cohen rightly noted, "The truth of such rumours is not at issue: the point is that they can be traced to certain elements in the societal reaction and they serve both to validate a mood and course of action, and to solidify a diverse crowd into a homogeneous mob." (Cohen 1972: 156) 
Altheide suggests that "Fear is a social product and not an individual failing. Fear is a manufactured response that has been produced by a mass-mediated symbol machine" (Altheide 2002: 23). With a constant stream of symbols churned out by this 'media machine'and the priming of pictures and symbols (Iyengar and Kinder 1987 cf. Altheide 2002: 25) of images dirt and disorder 'the Restaurant' became quickly associated with these dirty unappetizing images. As Cohen found in the case of the Mods and Rockers, "the symbols and labels eventually acquire their own descriptive and explanatory potential...Such symbolization is partly the consequence of the same standard mass communication processes which give rise to exaggeration and distortion" (Cohen 1972: 41).

Cribb himself duly noted (interview June 3,2005 ) that he was careful not to make direct connections between restaurants and incidents of food poisoning. Though he rightly noted that it would be virtually impossible to make definitive and direct causal relationships, the omission of food poisoning rates also contributed to the idea of the pervasiveness of severe health infractions. It is no wonder that many citizens claimed to boycott restaurants until something was done since for them, 'restaurant' was more or less equated with 'dirty infested establishment'- hardly appetizing let alone worth paying for.

The success of 'Dirty Dining' in the Toronto Star prompted the city's other newspapers and news stations to pick up on Cribb's investigative journalism story, the occasion of which is Cribb noted was very rare, as rivalries were highly competitive. For 
newspapers like Toronto Sun and the Globe and Mail to give attention to a story credited to the Star, it was obvious the level of public concern and interest.

\section{The "Real" Risks/Harms}

According to Lupton, "risk' may be understood as the cultural response to transgression: the outcome of breaking a taboo, crossing a boundary, committing a sin. At the heart of these 'risks' are the emotional dimensions of transgression: anger, anxiety, frustration, hatred, rage, fear" (Lupton 1999: 45). Anger directed towards restaurateurs were based on their moral transgression towards society in serving contaminated food. It was 'wrong' or 'immoral' because they were willingly and knowingly risking their customer's health. As Ewald asserted,

"The moment a population is identified as a risk, everything within it tends to become - necessarily becomes - just that. Risk has an allusive, insidious potential existence that renders it simultaneously present and absent, doubtful and suspicious. Assumed to be everywhere, it founds a politics of prevention. The term prevention does not indicate simply a practice based on the maxim than an ounce of prevention is worth a pound of cure, but also the assumption that if prevention is necessary it is because danger exists - it exists in a virtual state before being actualized in an offense, injury, or accident. This entails the further assumption that the responsible institutions are guilty if they do not detect the 
presence, or actuality, of a danger even before it is realized." (Ewald 1993: 221222)

The establishment of the folk devil as a risk to society is important because "Risk discourses provide apparently utilitarian grounds for regulatory intervention without appearing directly to institute a form of moral regulation" (Hunt 2003: 187). Though things later erupted into hysteria, in the case of the UK egg scare, an increase in the number of food poisoning and deaths incited original articles addressing the prevalence of salmonella in eggs, In contrast, there was no such increase of food poisoning accounts at the advent of 'Dirty Dining'. In other words, other than Robert Cribb's bout of food poisoning six months before he attained government information to write his articles, there was no evidence in an increase of hospitalizations or deaths related to dirty restaurants. Other than his investigative news serial, no event occurred in the food or restaurant industry that would have called for immediate attention.

One reader in the Toronto case expressed the opinion that,

"I am definitely eating less in restaurants....My wife and I even stopped ordering pizza and everything else where we can't see directly where it's being cooked."; “As a result of the articles in The Toronto Star, I just totally absolutely refuse to eat in any restaurant again, "a woman said.... On caller said she and her husband were planning to go out Saturday night but looked at each other and said: "No. 
Forget it. We'll cook at home. It's not worth taking the risk. "(Toronto Star, February 21, 2000: B3)

Another Star reporter, Royson James said,

"Eating out downtown is supposed to be a fairly risk-free undertaking. Hundreds of thousands depend on downtown eateries every day and night for sustenance. They rely on the diligence of health inspectors to ensure the food is being prepared in a healthy environment."(Toronto Star, Feb 25, 2000: B1)

A 90-year-old mother-in-law of one reporter commented on the events by claiming that she refused to eat out except for a few Jewish restaurants in her hometown in London. The reporter wrote, "You never know what's going on in those kitchens," she once told me conspiratorially, placing her face close to mine and giving me a knowing look" (Toronto Star, March 1: E5). Whereas her claims prior to 'Dirty Dining' may have been readily dismissed, now the paranoid conspiracy theorist becomes normalized.

A Starphone poll revealed that of the 1,953 readers who responded, $98.7 \%(1,928)$ said they were dining out less frequently since they've read about the problems with Toronto restaurants (Toronto Star, March 8, 2000, B2). Some asserted that they were going to boycott all Toronto restaurants until the problems are 'fixed' (February 21, 2000: A1; February 21, 2000: B1; March 1, 2000: E5), others vied they would never go to 
restaurants ever again (Toronto Star March 8 2000, B2.). The decreased number of patrons was noted by restaurant owners as well as consumers.

What did the people think they were risking? Was it that they believed that their health and lives were in danger, was it just that they didn't want to risk ingesting dirty food, or was it just risking the thought that they might be sitting at a restaurant only to see a cockroach scurry past? Obviously the chances and seriousness of these worries vary. But what were the 'real' risks involved? Aside from mice droppings and such, what was the 'objective harm' that citizens should have been concerned about?

"Toronto inspection data from the past two years (1998-99), obtained for the first time by The Saturday Star, show more than 750 restaurants in the old city received at least one citation for a "critical" food safety problem - the most serious kind of infraction, which can lead to food poisoning and other food-borne illnesses. Dozens of these restaurants show histories of food safety problems, but are still permitted to serve food to unwitting diners without penalty or public knowledge"(Toronto Star, February 19, 2000: A1).

When 'Dirty Dining' first came out, 1999 Health Canada statistics were published showing that 1,700 Torontonians were affected by food poisoning each year, while 42,500 more have food poisoning without realizing it. Note that the 1,700 total was the number reported from food poisoning in general, and not all cases may have been related to restaurant dining (supermarket food, home preparation, etc.) though this was not 
emphasized in the Star. Also, according to Statistics Canada, in the 1996 census, the old city of Toronto CMA (census metropolitan area) had a population of 4.3 million, so the number of reported cases is a small number. Proportionally, taking into account that 42,500 is an estimated number that includes food poisoning from sources other than restaurants is also not very significant. The fact that people may not even realize they have food poisoning shows that such 'risks' are not as dangerous or life threatening as it seemed. Cribb noted that many think of food poisoning as the severe kind, complete with diarrhea, but "some people just feel crappy" after eating tainted food and don't make the connection (Cribb interview June 3, 2005). Furthermore, while other horrific details of unclean environments were constantly repeated, these statistics were not. While it is unfortunate that some consumers may "feel crappy", this hardly poses a scare proportional to the fervour created by The Star.

It wasn't until March 8, 2000 that an article addressed 'real' health concerns, though it was a smaller article on the inside, unlike other articles that occupied prominent front-page space. In Vermin can be indicator of even greater health risk, Toronto Star staff reporter Janice Turner noted,

'The mice and cockroaches at your local dirty diner probably aren't your biggest health worry - unless they're carrying bacteria around on their wee tootsies. But they speak volumes about the place. It's hard to imagine that any establishment that tolerates rodents and insects is going to be fastidious about hand washing, food storage, handling and preparation."(Toronto Star, March 8, 2000: B2) 
Dr. Kevin Kain, director of the tropical diseases unit at the University Health Network, told readers that "Although not the source of bacteria, rodents and insects can spread the micro-organisms by moving from contaminated food on to clean food. Still, they're much more likely to be a sign of really bad levels of hygiene than a cause of foodborne illness", also noting that most causes of food poisoning was caused by bacteria like E. Coli, salmonella and campylobacter that give symptoms of vomiting, diarrhea, headache and fever for six to thirty-six hours after ingesting (Toronto Star, March 8, 2000: B2).

In interview, Cribb acknowledged that the risk "rests with chronic food violations and safety threats" and "the fear of the unknown" (interview June 3, 2005). Though it was mentioned and inferred that dirty restaurants have a causal relationship to illness, it was only left to the reader to assume that the argument for disclosure of inspection results would subsequently 'clean up' restaurants, thereby lowering instances of contamination.

\section{The UK egg-scare}

From November to March (1988-89) a similar fear of contaminated food erupted in the UK. In a case study by Roger Fowler, he found that in these three months, what he called a 'mass hysteria' pervaded the British media. 
"There was a panic about food poisoning, and specifically about two types of bacterial poisoning the incidence of which allegedly had been increasing alarmingly: salmonella poisoning caused by the strain Salmonella enteritidis phage type 4, apparently newly discovered to be present in eggs (as opposed to poultry meat); and listeriosis, a flu-like illness caused by Listeria monocytogenes, a bacterium occurring widely in the environment and now found in pre-cooked and chilled food, and some cheeses. Food poisoning 'cases' and 'outbreaks' had apparently increased substantially in numbers over recent years and months and during the panic of that winter, a few deaths and stillbirths specifically linked to salmonella and listeria occurred or were reported." (1991: 146).

According to the author, the "great egg scare was not a medical phenomenon, not an epidemic; it was a construct of discourse, a formation and transformation of ideas in the public language of the newspapers and television" (Fowler 1991: 148). Contrary to the Toronto restaurants example, there was evidence of heightened cases of food poisoning and deaths at the time of the panic which more immediately addressed the dangers of the food. Like the Toronto example, however, Fowler noted the heavy role that the British media played in this hysteria, maintaining a high focus on egg and cheese products, "reporting all statements by politicians and experts, giving statistics, dispensing advice, investigating producers and retail outlets, commenting on the responsibilities and short comings of the government departments involved" all the while expanding the scope of fear to include other things like the aluminum coating on sweets and pesticide residues in cereal. Concern was heightened to embrace the cleanliness of shops, 
restaurants, kitchens, and places of commercial food processing and other possible malaises identified (Fowler 1991: 146-7). Though the issue started in November 1988, it wasn't until February 1989 that "the topic was fully established in the Press, and indeed escalating in its daily production of new instances of danger and scandal." In just oneand-a-half months, Fowler collected 300 reports and features related to the 'great egg scare'. Though most of these were from reputable newspapers and occupied prominent space, the nature of the hysteria became obvious as headlines like Toenail in MP's food (Sun, February 3), Neglected rivers die in stench of scandal (Sunday Times, 5 February), 20 ways to beat the killers in your kitchen (Sun, 13 February), and Farmers despair over milk shaker that threatens to devastate their lives (Express, 13 February) (cf. Fowler 1991: 156-7). As Critcher noted, this egg scare "indicates how critical linguistics can uncover the mechanics of a specific discourse" and how, in this case, hysteria was directly attributable to the articles published in British news media during this time (Critcher 2003: 171).

Despite the similar circumstances, what distinguishes the situation in Toronto was the end product that resulted from the actions taken by the moral entrepreneur, public and the media. While the UK egg-scare eventually fizzled out and lost the interest of the general public, the 'Dirty Dining' serial and resulting outcry were major contributors to the implementation of new government policies around restaurant grading. In the next chapter, I examine the process of how this government action came about and speculate on the contributing factors which made this moral panic uniquely effective in bringing about change. 


\section{Chapter 3: The Solution and Agenda}

The Blitz

Within twenty-four hours of the debut of Dirty Dining, municipal and provincial politicians were faced with a barrage of public outrage that eventually ensured a change in policy with respect to the publication of restaurant inspection results, and subsequently the introduction of a restaurant grading card system, now commonly known as DineSafe. The Toronto Star was sure to include at least one article under the special heading of 'Dirty Dining' every day for the first few months, with the majority of them located on the front page or the first section of the newspaper; also, these articles also frequented the front page of the newspaper's "Greater Toronto" section. Officials themselves recognized that the city's changes in the restaurant health inspection were directly attributable to the Star investigation (Toronto Star, February 24 2000: A1).

Almost immediately, the mayor ordered an inspection crackdown on the 4000 restaurants in the old city of Toronto. This blitz eventually lasted four months and led to 60 restaurant closures and more than 100 charges laid. Many were excited, noting that it was the highest rate of restaurant health enforcement in the City's history (Canadian Association of Journalists, Summer 2001). Whereas the inspection system was criticized for the inadequate number of inspectors, and the frequency and thoroughness of their inspection, Lastman ordered the hiring of 24 inspectors, with an estimated cost of $\$ 2.3$ million, to concentrate on 'cleaning up' dirty restaurants in the first days of the blitz (Toronto Star, February 23, 2000: A1). As health inspectors are responsible for duties other than restaurant inspection, for the period of the blitz, they were pulled away from 
their regular duties. The announcement of the blitz assured Torontonians that the government was 'doing something'. The provincial government also made comments about providing support for the new system (Toronto Star, February 22, 2000: A1), and other surrounding areas began looking into enacting systems of disclosure.

Since the debut of 'Dirty Dining', Robert Cribb repeatedly emphasized the importance of disclosure, readily offering his solution to the restaurant 'problem' by introducing a grade card option like to the Los Angeles scheme. This was hinted at in the very first article, but was expanded on in detail and repeatedly addressed afterwards. In addition, Cribb also advocated the detailed disclosure of restaurants inspections by calling a phone line or accessing a website made available by the City of Toronto. Readers wrote in to express their support for a system that posted grade inspections of restaurants clearly in windows such that diners would know the results of the establishment's most recent health inspection. Mel Lastman was also in favour of inspection postings (Toronto Star, February 21, 2000: A1), while some criticized government officials, charging that they were trying to capitalize on the Star's reports because it was an election year and that they were overstepping their boundaries because restaurant inspections were supposed to be the responsibility of health officials (Toronto Star, March 16, 2000: B4). While Sheila Basrur, the city's Medical Officer of Health, contested that " $(\mathrm{t})$ his information is in the public domain" (Toronto Star, February 26, 2000: A1) and Ontario Consumer Minister Bob Runciman said that the City of Toronto did have the authority to publish names of eateries putting people at risk (Toronto Star, March 2, 2000: A1), while others like John Filion (Chair of the Board of Health) 
wondered if health inspectors had the authority to publish inspection results (Toronto Star, March 10, 2000: B3). Lastman also called for the support of then Ontario Premier Mike Harris, who expressed his support (Toronto Star, March 2, 2000: A1). In addressing the issue, Filion agreed that " $(\mathrm{t})$ he consumer has a right to know what they're going out to eat, whether it's a clean place or not....If you're not clean, everyone will know and you'll lose a lot of business" (Toronto Star, February 20, 2000: A1).

In the memorable words of Mel Lastman, "The people are fed up. They want to know what the hell they're eating." (Toronto Star, February 26, 2000: A1). He announced a two-week blitz which was highly beneficial because it not only showed the citizens that he was 'doing something', but it started the movement that eventually led to grade card posting. Each time Toronto Public Health closed down a restaurant, The Toronto Star reported it. This reinvigorated public outcry as it became obvious that some restaurants did operate in filthy conditions. While anecdotes before were quite vague about dirty restaurants, Toronto Public Health was building a growing list of identified names so that the public had targets to act upon. To retain the interest of the general readership, the Star had daily reports of new restaurants that were closed and the detailed reasons why, usually with a focus on improper hand washing, mice and cockroach infestations.

There was little opposition to the public disclosure, with the general opinion of "what do they have to hide?" which vilified those who complained about the new harsher way the city was dealing with the situation. Those who noted that where there was food 
there was often vermin, and that the most they could do was to minimize it were not accepted. An owner of a Chinese restaurant complained that the health standards of maintaining food temperatures did not coincide with the traditional method of cooking tofu (Toronto Star, March 3, 2000: A24). Others noted that they would have to suffer great financial loss if they had to pay for required renovations (Toronto Star, March 11, 2000: A9). Nevertheless, it was widely agreed that the old educational method of trying to educate food handlers just was not successful. Rather, they had to be 'hit where it hurt' (Toronto Star, Letters, February 26, 2000: K7), that is, if the restaurants were dirty they should be fully disclosed so that business would suffer until they 'clean up their act'. According to the then-superintendent of food inspection in Montreal, Christine Vezina, "Publishing makes a big difference....(Restaurant operators) are more willing to comply. We see a big difference in their reactions. They'll say, 'Give me a fine, but don't publish it."' (Toronto Star, February 20, 2000: A1)

The Star repeatedly emphasized that of the 750 restaurants they found to have serious health infractions in the two previous years (1999-2000), only 11 were closed down. Of the reasons given to explain why inspectors did not do a better job, the most prominent included a lack of funding for the system and too few inspectors. Health officials noted that most food poisoning outbreaks are linked to the food service industry, with Toronto's food-borne illness rate 30-40\% higher than Ontario's average (Toronto Star, February 20, 2000: A1). These facts infuriated the public, and helped to reinforce the Star's main point that the system had to be reformed. While no Canadian city at the time had a restaurant grading card system in place, Ottawa had a telephone hotline on 
restaurant inspections, cafeterias, and caterers; Vancouver posted places closed by inspectors on the internet, and Montreal had an internet list of restaurants fined (Toronto Star, February 20, 2000: Al). These examples showed the interest that Canadians had in restaurant disclosure and how similar ideas were used and well-received in many Canadian cities.

While there was a general decrease in restaurant patronage, specific restaurants inspected by the blitz experienced almost irreparable damage to both finances and reputation. In one case, when Beemah was closed, restaurant owners and shop keepers in the vicinity also noted a marked decrease in sales, directly relating the drop to the negative publicity that their neighbour received. Soon restaurants began proactively cleaning up, for fear that they might be targeted. The Blue Begonia passed inspection and publicized it themselves by posting a huge "WE PASSED! City of Toronto food premises inspection report. Join us for Sunday Brunch" in their window. (Toronto Star, March 10, 2000: B3)

Cribb's suggestion of restaurant grade card postings produced a central cause behind which the public, the government, and eventually the restaurants rallied. This focused support made the restaurant grade card postings an instant front runner in the list of available actions, and the resulting momentum helped propel the proposal through the local government's agenda. Royson James, another Star reporter, claimed that the Toronto Star story "cleared aside the administrative hurdles" after years of "gobbbledegook answers" given by the government regarding the lax inspection system 
(Toronto Star, February 25, 2000: A1). However, while John Filion, then chairman of the Toronto Board of Health, claimed that he had proposed a disclosure system since November 1999, he noted the Star's significant role in enacting a new system. (Toronto Star, March 2, 2000: A1)

\section{Toronto's DineSafe Program}

The city originally had an "education-based" approach that only used punitive measures as a last resort (Toronto Star, February 26, 2000: A1). In the 1990s, Hazard Analysis Critical Control Point inspections were introduced and according to representatives from the Canadian Institute of Public Health Inspectors, were undertaken in an attempt to make inspections more standardized. It was possible to lay charges under the Health Protection and Promotion Act (HPPA), but there was no fine under this Act (Letters, Toronto Star, February 29, 2000: A27). The general consensus was that through publication of health inspection results, the "dirty" restaurants would gradually be phased out of the industry by their cleaner competitors. There was also an emphasis on the restaurants being more accountable to their patrons. It was believed that the education-based approach provided little incentive for owners to keep their restaurants clean, and did little to deter re-offending because punitive measures did not "hit them where it hurts" (Letters, Toronto Star, February 26: K7), that is, economically. Rather, fines for breaching municipal health standards were between $\$ 35$ and $\$ 125$, with the average fine given to restaurants only $\$ 45$. Though the Toronto Board of Health encouraged food handlers to take training courses, it was not mandatory and employers 
often complained that the $\$ 35$ fee was too costly for them to send their employees (Toronto Star, February 21, 2000: A1). This is important because it was found that restaurants with at least one employee on hand with certification greatly improved clean practices of the restaurant which in turn are directly related to incidents of food borne illnesses (Toronto Star, February 19, 2000: A1).

Through the immense amount of unanticipated public support, the municipal government of Toronto eagerly adopted Cribb's solution to end Dirty Dining in Toronto through use of publicly posted grade cards like the ones existing in Los Angeles and Chicago. The once lenient and ineffective educational approach that encouraged restaurateurs to follow health standards was revised to include disclosure of results, more diligent inspection processes, and increased punishment for offenders. Almost a year after Cribb's first article appeared, Toronto became the first city in Canada to enact its Health Inspection and Disclosure (DineSafe) program in January, 2001.

Toronto health inspectors now go by the 8-Step Rules program when inspecting food establishments, which is published on their website (http://app.toronto.ca/food2/steps.jsp). This provides a detailed checklist of specific, measurable criteria upon which to make judgments. Previously, inspectors followed vaguer criteria and looked more generally at 1) Critical violations that could lead to sickness or death (such as improper cooking, serving, and storage temperatures; unwashed hands; cross-contamination); and 2) Non-Critical violations (general housekeeping and hygiene of food handlers, garbage disposal, and smoking) (Toronto 
Star, February 19, 2000: A1). As opposed to the previously lax inspection staff and inspection schedule, the new program saw between 500 and 600 inspections completed per week by a staff of 72 inspectors. (Toronto Star, January 9, 2001: F4)

Penalties for health infractions were increased, and court appearances with fines as high as $\$ 5,000$ for individuals or $\$ 25,000$ for businesses (Toronto Star, February 29 , 2000: B2) in the most serious cases. Depending on the type food preparation methods, eating establishments were to be inspected from one to three times a year and the results of the inspections displayed prominently in the window. Cards come in three colours: green for "Pass", yellow for "Conditional Pass", or red for "Fail". Restaurants that receive a conditional pass are inspected within 24 hours to ensure that infractions have been corrected. If not, the restaurant can be closed down until sufficient corrections are made. Restaurants that are found to have critical violations receive a "Fail" are immediately closed until infractions are fixed and severe or repetitive violations are subject to fine or imprisonment through criminal law. Detailed histories of each inspection are listed on the city's web site (accessible at www.city.toronto.con.ca/fooddisclosure/) or can be accessed a telephone hotline (416338-3663). (Toronto Star, January 9, 2001: F1, F4). Other Canadian and international cities look to the Toronto example, eager to implement a similar program to follow suit. ${ }^{5}$

\footnotetext{
${ }^{5}$ Though to date no other Canadian city has followed through, there is evidence of expressed interest and initial stages of planning (eg. Ottawa).
} 


\section{Conclusion}

When Cribb first embarked on his 'Dirty Dining' series, he did not anticipate the level of intense public interest that resulted. Four years later, he still receives inquires by tourists claiming that they are aware of his articles and asking him for advice on which restaurants are safe to patronize. The success of the articles in generating change should be attributed to the media, without which this moral entrepreneur would have difficulty enacting change. However, the media is not the sole reason why his campaign was successful. There are many issues that newspapers like The Toronto Star print every day. Few have the lasting impact or retain strong public interest for so long, and result in a direct and expedient change to government policy. In short, few have the elements of a moral panic. In the case of 'Dirty Dining', Robert Cribb did extensive research and used his influence to present the 'facts' to the public. Few people, let alone reporters, are accorded the time and resources to do the level and depth of research that Cribb did. Prior to his series, stories of food poisoning and dirty restaurants took the form of sporadic anecdotes which were easily brushed aside and forgotten. After obtaining the

government records, Cribb was able to show trends and figures that emphasized how dire the situation was. According to him, it was the first time that his thorough analysis was able to draw strong, undeniable conclusions. He then quickly discovered that "this story had legs", and it is the public that decides which stories they want to hear about. The high level of response can also be attributed to the fact that restaurants are one of the rare issues that affects everyone in the city whereas other public health issues like the conditions of schools or nursing homes affect a smaller population (interview, June 3 , 2005). 
The Dirty Dining series resonated with people on many different levels. It touched on risk and the unknown, not getting what you pay for, ingesting unknown and unseen substances, the "natural" aversion that most have towards rodents and insects. As Cohen noted, "At times of moral panic, societies are more open than usual to appeals to this consensus: 'No decent person can stand for this sort of thing.' The deviant is seen as having stepped across a boundary which at other times is none too clear" (Cohen 1972: 75). In the case of restaurants, once it was shown that restaurateurs were blamed for knowingly feeding consumers dirty food, it was difficult for anyone to deny that this was 'wrong. As the Chair of the city's Board of Health, John Filion noted, "We are dealing with a crisis of public perception and we need to respond to that as much as we do to the actual problem" (Toronto Star, March 2, 2000: A22 ). Nevertheless, with the level of public outrage that ensued, it was difficult for the authorities to ignore it. Cribb's extensive research into the grade card postings of cities like Los Angeles and Chicago expedited the process of 'doing something' about the issue. He proposed a clear model for Toronto which eventually fueled a debate at City Hall and resulted in "virtually a mirror of what we asked for". Most importantly, he noted that if he did not suggest this solution, there "may not be a disclosure system, or one that works" today. Four years after its enactment, the DineSafe website is among the city's most visited sites and in a poll of both restaurant owners and customers reported a $75 \%$ support rate (Cribb interview, June 3, 2005). Kudos to this moral entrepreneur who has since expanded his plight towards government disclosure (Toronto Star, May 28, 2000: via thestar.ca). 
An underlying issue encountered in this study was the disproportionate mention of lower-end ethnic restaurants throughout the 'Dirty Dining' series. Though an analysis of this discrepancy was beyond the scope of this thesis, future research directed at investigating ethnic and class-based differences may shed light on the possible role of stereotypes in moral panics as well as suggest another dimension to how the Toronto example was so successful. 


\section{Bibliography}

\section{Books and Journals}

Astroff, R.J. and A.K. Nyberg (1992). "Discursive hierarchies and the construction of crisis in the news: a case study". Discourse and Society 3(1): pp. 5-24.

Altheide, David L. (2002). Creating fear: news and the construction of crisis. New York: Aldine de Gruyter.

Aronson, Naomi (1984). "Science as claims-making activity: implications for social problems research." In Joseph W. Schneider and John J. Kitsuse (eds), Studies in the Sociology of Social Problems. Norwood, NJ: Ablex, pp. 1-30.

Becker, Howard (1963). Outsiders: Studies in the Sociology of Deviance. New York: Free Press.

Ben-Yehuda, Nachman (1985). Deviance and Moral Boundaries: Witchcraft, the Occult, Science Fiction, Deviant Sciences and Scientists. Chicago: University of Chicago Press.

Bromley, David G. (1991). "Satanism: the new cult scare." in James T. Richardson, Joel Best, and David G. Bromley (eds.), The Satanism Scare. New York: Aldine de Gruyter, pp. 49-72.

Cohen, Stanley (1972). Folk Devils and Moral Panics: The Creation of the Mods and Rockers. London: MacGibbon \& Kee.

Critcher, Chas (2003). Moral Panics and the Media. Buckingham: Open University Press.

Davis, Nanette J., and Clarice Stasz (1990). Social Control of Deviance: A Critical Perspective. New York: McGraw-Hill

Ericson, R.V., P.M. Baranek, J.B.L. Chan (1987). Visualizing Deviance: a study of news organization. Toronto: University of Toronto Press.

Ewald, Francois (1993). "Two Infinities of Risk." in Brian Massumi (ed.), The Politics of Everyday Fear. Minneapolis: University of Minnesota Press, pp. 221-228.

Fowler, Roger (1991). Language in the News: Discourse and Ideology in the Press. London: Routledge.

Goode, Erich and Nachman Ben-Yehuda (1994). Moral Panics: the social construction of deviance. Cambridge, MA: Blackwell Publishers. 
Gusfield, Joseph R. (1963). Symbolic Crusade: Status, Politics and the American Temperance Movement. Chicago: University of Illinois Press.

Hall, Stuart, Chas Critcher, Tony Jefferson, John Clarke, and Brian Roberts (1978). Policing the Crisis: Mugging, the State, and Law and Order. London: Macmillan.

Halloran, J.D., P. Elliot and G. Murdock (1970). Demonstrations and Communication: A Case Study. Harmondsworth: Penguin.

Hunt, Alan (1999). Governing Morals: A Social History of Moral Regulation. Cambridge: Cambridge University Press.

Hunt, Alan. (2003). "Risk and Moralization in Everyday Life" in Richard V. Ericson and Aaron Doyle (eds.) Risk and Morality. Toronto: University of Toronto Press; pp. 165-192.

Jenkins, P. (1992). Intimate Enemies: Moral Panics in Contemporary Great Britain. New York: Aldine de Gruyter.

Kitsuse, John I., and Joseph W. Schneider (1989). "Preface" in Joel Best (ed.), Images of Issues: Typifying Contemporary Social Problems. New York: Aldine de Gruyter, pp. xi-xiii.

Lang, K. and G. Lang (1955). "The inferential structure of political communications". Public Opinion Quarterly, 19(summer).

LeBon, Gustave 1982 (1895). The Crowd: A Study of the Popular Mind. Marietta: Larlin.

Lupton, D. (1999). Risk: A Sociological Theory. New York: Aldine de Gruyter.

Mackay, Charles (1932). Extraodinary Delusions and the Madness of Crowds (oringinally published in 1841 under the title, Memoirs of Extraordinary Popular Delusions, $2^{\text {nd }}$ ed., published 1852). New York: L.C. Page.

McRobbie, Angela and Sarah L. Thornton (1995). "Rethinking 'moral panic' for multimediated social worlds". British Journal of Sociology, 46(4) (December): 559-74.

Rocheron, Y. and O. Linné (1989). "AIDS, moral panic and opinion polls". European Journal of Communication, 2(3): 13-18.

Sinclair, Andrew (1962). Prohibition: The Era of Excess. London: Faber \& Faber.

Springhall, John (1998). Youth, popular Culture and Moral Panics: Penny Gaffs to Gangsta-Rap, 1830-1996. New York: St. Martin's Press. 
Thompson, Kenneth (1998). Moral Panics. London: Routledge.

Turner, Ralph H., and Samuel J. Surace (1956). "Zoot-suiters and Mexicans: symbols in crowd behavior." American Journal of Sociology, 62 (July): 14-20.

Young, Jock (1971). 'The role of the police as amplifiers of deviance, negotiators of drug control as seen in Notting Hill', in S. Cohen (ed.) Images of Deviance, Harmondsworth: Penguin.

Watney, S. (1988). "AIDS, "moral panic' theory and homophobia" in R. Aggleton and H. Homans (eds) Social Aspects of AIDS. London: Falmer.

Woolgar, Steve, and Dorothy Pawluch (1985). "Ontological gerrymandering: the anatomy of social problems explanations." Social Problems, 32 (February): 21327.

Zatz, Marjorie S. (1987). "Chicano youth gangs and crime: the creation of a moral panic." Contemporary Crises, 11(2): 129-58.

\section{Toronto Star Articles}

February 19, 2000: A1. "Dirty Dining" by Robert Cribb; Toronto Star.

February 20, 2000: A1. "Many cities release restaurant reports; why can't Toronto" by Robert Cribb; Toronto Star.

February 21, 2000: A1. "Lastman orders blitz on Dirty Dining" by Robert Cribb; Toronto Star.

February 21, 2000: B1. "Toronto's inspection system gets an F" by Robert Cribb and Jennifer Quinn; Toronto Star.

February 22, 2000: A1. "Restaurant inspection crackdown starts now" by Robert Cribb; Toronto Star.

February 22, 2000: B7. "Dirty dining scandal called a distraction" by Rebecca Bragg; Toronto Star

February 23, 2000: A1. "Shoddy eateries to be named this week" by Robert Cribb; Toronto Star.

February 24, 2000: A1. "Critics say cleanup blitz should have come sooner" by Robert Cribb; Toronto Star. 
February 25, 2000: B1. "We're fed up with excuses in eatery mess" by Royson James; Toronto Star.

February 26, 2000: A1. "Health inspectors fail 53 restaurants" by Robert Cribb; Toronto Star.

February 26 2000: K7. "There's a fly in my soup - or is that a cockroach?" - Fan Wahn. Letters, Toronto Star

February 26 2000: K7. "Let dining industry self-regulate"- Murray Smith. Letters, Toronto Star.

February 26, 2000: K7. "Cleaner dining: Here's food for thought"- Jim McCarty. Letters, Toronto Star.

February 26, 2000: K7. "Let's hit restaurants where it hurts" - Karina Andersen-Casp. Letters, Toronto Star.

February 26, 2000: K7. "Difficult threesome doesn't work" - Alexander Franklin. Letters, Toronto Star.

February 26, 2000: K7. "Let postings be voluntary" - Samuel P. Jarvis. Letters, Toronto Star.

February 26, 2000: K7. "Accomplices now play hardball" - Lee Jasper. Letters, Toronto Star.

February 26, 2000: K7. "Inspection reports should be routinely available" - Tom Mitchinson. Letters, Toronto Star.

February 29, 2000: B1. "Second restaurant forced to close" by Robert Crib; Toronto Star.

February 29, 2000: A27. "Health inspectors need enforcement tools" by Michael Duncan and Judith de Groisbois. Letters, Toronto Star.

March 1, 2000: A1. "Health inspectors shut down mice-infested grocery store" by Robert Cribb; Toronto Star.

March 1, 2000: E5. "It's time to clean up this city's dirty dining" by Marion Kane; Toronto Star.

March 2, 2000: A1. "'Media spotlight' forces move" by Robert Cribb; Toronto Star.

March 3, 2000: A1. "Three more restaurants forced to close" by Robert Cribb; Toronto Star. 
March 3, 2000: A27. "If the bathroom's dirty, imagine the kitchen" - Leslee Hiebert. Letters, Toronto Star.

March 4, 2000: A1. "'Very scary' bakery shut down" by Robert Cribb; Toronto Star.

March 4, 2000: A15. "Word of mouth chokes restaurants" by Jim Coyle; Toronto Star.

March 4, 2000: H6. "Rats! A rodent rumpus is settled at last" by Don Sellar; Toronto

March 5, 2000: A1. "'Mystery Bread' sparks new fears over safety" by Robert Cribb; Toronto Star.

March 5, 2000: A12. "Check shops" - June Adams. Letter, Toronto Star.

March 6, 2000: B1. "Food safety blitz urged in Peel" by Mike Funston; Toronto Star.

March 7, 2000: A1. "Another eatery down" by Robert Cribb and Nicholas Keung; Toronto Star.

March 8, 2000: B1. "Another eatery closed by city health" by Robert Cribb; Toronto Star.

March 8, 2000: B2. "GTA-wide standards sought" by Leslie Ferenc; Toronto Star

March 8, 2000: B2. "Fewer people dine out, poll says" by Tracy Huffman; Toronto Star.

March 8, 2000: B2. "Vermin can be indicater of even greater health risk" by Janice Turner; Toronto Star.

March 8, 2000: A27. "Where is city's clean dining?" - Charles Cook. Letters, Toronto Star.

March 9, 2000, D1. "Eateries clean up dirty secrets" by Robert Cribb; Toronto Star.

March 9, 2000: A31. "What about legions of mice in beer brewing plants?"- Bogdan Kadej. Letters, Toronto Star.

March 9, 2000: A31. "List clean dining spots, too"- Don MacNeill. Letters, Toronto Star.

March 9, 2000: A31. "Education is needed in food industry" - Rudolf Mannok. Letters, Toronto Star.

March 10, 2000: B3. "Inspectors uncover 'mountain' of health violations" by Robert Cribb; Toronto Star.

March 10, 2000: A27. "Bring your own mints" - Don Nesbitt. Letters, Toronto Star. 
March 11, 2000: A9. "Two more eateries closed" by Robert Cribb; Toronto Star.

March 11, 2000: K5. "Dine and dash - a new Olympic event" The Skinny on City Hall; Toronto Star.

March 15, 2000: B1. "And what will the neighbours think" by Royson James; Toronto Star.

March 16, 2000: B4. "Fear driving eateries to clean up" by Robert Cribb; Toronto Star.

March 16, 2000: B3. "Eatery infested with rats closed" by Lily Nguyen; Toronto Star.

March 18 2000: B4. "Fear driving eateries to clean up" by Robert Cribb; Toronto Star.

March 19, 2000: A27. "Clean up or I'll eat at home" - Ewan Thompson. Letters, Toronto Star.

March 22, 2000: B5. "Bakeries fare worse than eateries in blitz"' by Lily Nguyen; Toronto Star.

March 22, 2000: A27. "Eating on the floor truly dirty dining" - Shirley Bush. Letters, Toronto Star.

March 24, 2000: B1. "Dirty diners just one item on a full plate" by Royson James; Toronto Star.

March 25, 2000: B4. "Eateries blitz is succeeding, city official says" by Nicolaas van Rijn; Toronto Star.

March 27, 2000: A21. "Who's been policing city health inspectors?" - Michael Crane. Letters, Toronto Star.

March 27, 2000: A21. "Confidence in inspectors has been lost" - Bernard Lewis. Letters, Toronto Star.

April 1, 2000: A1. "How California keeps it clean" by Robert Cribb; Toronto Star.

April 3, 2000: A18. "A plan to end 'dirty dining' in the city" by Douglas P. Fisher; Toronto Star.

April 3, 2000: A19. "Eating off floor no picnic" - Rita Pagel. Letters, Toronto Star.

April 5, 2000: B4. "Filthy eatery passed March test" by Robert Cribb; Toronto Star.

April 7, 2000: B2. "Eatery monitor offers $\$ 150$ seal of approval" by Robert Cribb; Toronto Star. 
April 16, 2000: A8. "Province-wide eatery ratings sought" by Robert Cribb; Toronto Star.

April 21, 2000: A9. "Restaurant crackdown comes to Ottawa region" by Robert Cribb; Toronto Star.

January 1, 2001: A1. "Dining health alerts up this week" by Robert Cribb; Toronto Star.

January 9, 2001: F1. "Restaurant's ratings debut" by Robert Cribb; Toronto Star.

January 11, 2001: A27. "Laurels for restaurant inspection system" by Yvonne Blackwood; Toronto Star.

January 11, 2001: B4. "Failed eater gets pass" by Karen Palmer; Toronto Star.

January 12, 2001: B3. "Health inspectors close four establishments" by Andrew Chung; - Toronto Star.

January 13, 2001: As. "Mayor talks tough after first week of restaurant ratings" by Karen Palmer; Toronto Star.

January 20, 2001: B3. "Restaurant gets red card" (graph); Toronto Star.

\section{Internet Resources}

The Canadian Association of Journalists (CAJ) Awards- Computer Assisted Reporting (CAR) Category; accessed October 31, 2004.

<www.caj.ca/mediamag/summer2001/caraward.html>.

May 28, 2005. "Access Denied- Access laws are supposed to help Canadians get information from government. But a cross-country audit has found many agents of government are just saying no" by Robert Cribb and Fred Vallence-Jones via <www.thestar.com> accessed August 4, 2005.

City of Toronto DineSafe Website $<$ www.city.toronto.con.ca/fooddisclosure/s.

\section{Interview}

Interview with Robert Cribb, staff reporter at the Toronto Star newspaper and professor at the Ryerson School of Journalism; June 3, 2005. 